\title{
Immunoproteomic Analysis Reveals Novel Candidate Antigens for the Diagnosis of Paracoccidioidomycosis Due to Paracoccidioides lutzii
}

\author{
Anderson Messias Rodrigues $1, * \mathbb{C}$, Paula Helena Kubitschek-Barreira ${ }^{2}$, \\ Breno Gonçalves Pinheiro ${ }^{1}{ }^{(\mathbb{C}}$, André Teixeira-Ferreira ${ }^{3}{ }^{(0)}$, Rosane Christine Hahn ${ }^{4,5}$ \\ and Zoilo Pires de Camargo 1,6,* \\ 1 Laboratory of Emerging Fungal Pathogens, Department of Microbiology, Immunology, and Parasitology, \\ Discipline of Cellular Biology, Federal University of São Paulo (UNIFESP), São Paulo 04023062, Brazil; \\ brenogonpi@gmail.com \\ 2 Department of Cellular Biology, Roberto Alcantara Gomes Institute of Biology, Rio de Janeiro State \\ University (UERJ), Rio de Janeiro 20511010, Brazil; paulahkb@gmail.com \\ 3 Toxinology Laboratory, Department of Physiology and Pharmacodynamics, Fiocruz, \\ Rio de Janeiro 21040900, Brazil; atsferreira@gmail.com \\ 4 Laboratory of Mycology/Research, Faculty of Medicine, Federal University of Mato Grosso, \\ Cuiabá 78060900, Brazil; rchahn@terra.com.br \\ 5 Júlio Muller University Hospital, Federal University of Mato Grosso, Cuiabá 78048902, Brazil \\ 6 Department of Medicine, Discipline of Infectious Diseases, Federal University of São Paulo (UNIFESP), \\ São Paulo 04023062, Brazil \\ * Correspondence: amrodrigues@unifesp.br (A.M.R.); zpcamargo1@gmail.com (Z.P.d.C.); \\ Tel.: +55-1155764551 (ext. 1540) (A.M.R.); +55-1155764551 (ext. 1512) (Z.P.d.C.)
}

Received: 16 November 2020; Accepted: 8 December 2020; Published: 11 December 2020

check for updates

\begin{abstract}
Paracoccidioidomycosis (PCM) is a life-threatening systemic infection caused by the fungal pathogen Paracoccidioides brasiliensis and related species. Whole-genome sequencing and stage-specific proteomic analysis of Paracoccidioides offer the opportunity to profile humoral immune responses against $P$. lutzii and $P$. brasiliensis s. str. infection using innovative screening approaches. Here, an immunoproteomic approach was used to identify PCM-associated antigens that elicit immune responses by combining 2-D electrophoresis of $P$. lutzii and P. brasiliensis proteomes, immunological detection using a gold-standard serum, and mass spectrometry analysis. A total of 16 and 25 highly immunoreactive proteins were identified in P. lutzii and P. brasiliensis, respectively, and 29 were shown to be the novel antigens for Paracoccidioides species, including seven uncharacterized proteins. Among the panel of proteins identified, most are involved in metabolic pathways, carbon metabolism, and biosynthesis of secondary metabolites in both immunoproteomes. Remarkably, six isoforms of the surface-associated enolase in the range of $54 \mathrm{kDa}$ were identified as the major antigens in human PCM due to P. lutzii. These novel immunoproteomes of Paracoccidioides will be employed to develop a sensitive and affordable point-of-care diagnostic assay and an effective vaccine to identify infected hosts and prevent infection and development of human PCM. These findings provide a unique opportunity for the refinement of diagnostic tools of this important neglected systemic mycosis, which is usually associated with poverty.
\end{abstract}

Keywords: immunoproteomic; proteomic; Paracoccidioides brasiliensis; Paracoccidioides lutzii; paracoccidioidomycosis; serology; diagnosis; endemic mycosis; systemic mycosis; biomarker

\section{Introduction}

Paracoccidioidomycosis (PCM) is a life-threatening systemic infection caused by the fungal pathogen Paracoccidioides brasiliensis and related species. The disease was first described in Brazil 
in 1908 by Adolfo Lutz [1], followed shortly thereafter by reported infections in a wide area of the Americas. The genus Paracoccidioides was described in 1930 by Floriano de Almeida [2], and currently it infects at least 10 million people [3,4], being the most prevalent systemic mycosis in Latin America $[5,6]$. The incidence of PCM is estimated to be one to three cases per 100,000 inhabitants, and the majority of cases occur in endemic areas of Brazil, Colombia, and Venezuela [6,7]. The characteristics of the work environment can play a role, together with other risk factors, in PCM development. Therefore, PCM has been mostly reported in male rural workers during the most productive years of their lives, which poses a significant public health problem and causes substantial economic losses. Mortality associated with PCM varies between 6.1\% [8] and 7.6\% [9], ranking it as the eighth most common cause of death among infectious and parasitic chronic diseases [10].

Patients become infected after inhaling Paracoccidioides propagules from the environment, leading to primary pulmonary infection in the vast majority of human cases. In the host tissue, Paracoccidioides undergoes a thermodimorphic transition at $37^{\circ} \mathrm{C}$ and develops as a multibudding yeast [11]. The temperature-induced switching of Paracoccidioides species from a saprophytic filamentous morphotype in the soil at $25^{\circ} \mathrm{C}$ to a pathogenic budding yeast form in the human host is an essential morphological adaptation shared with other dimorphic pathogens in the Onygenales. While the disease is classically characterized by pulmonary involvement and systemic infections, lesions in the cutaneous and subcutaneous tissues with regional lymphocutaneous dissemination may also occur [12-14].

The criteria for laboratory diagnosis of PCM rely on positive microscopic identification of the causative agent in $\mathrm{KOH}$ preparations or biopsy specimens, where it is possible to visualize large yeasts (usually $5-15 \mu \mathrm{m}$ ) that have a thick, birefringent cell wall with single or multiple buds in a "steering wheel" or "Mickey Mouse" shape and are considered pathognomonic in the diagnosis of PCM [15]. The reference method for the definitive diagnosis is the isolation of the fungus in vitro from clinical material such as sputum or tissue fragments [15]. Even though classical techniques offer essential information due to the presence of pathognomonic forms of Paracoccidioides spp., nucleic acid-based diagnostic techniques are gradually replacing or complementing culture-based and biochemical assays in the routine of microbiology laboratories [16].

Serological assays are an essential aid in the clinical laboratory, as they provide a presumptive diagnosis and prognosis of the disease and represent an important tool for PCM patients' follow-up during treatment [17-20]. Serological tests can be directed towards detecting circulating antibodies or circulating antigens in various biological fluids, such as serum, bronchoalveolar lavage, cerebrospinal fluid, sputum, etc. We highlight the routine use of double immunodiffusion (DID), which allows the quantitative detection of circulating antibodies in PCM [21,22]. Serological assays also include techniques such as counterimmunoelectrophoresis reaction (CIE) [23], enzyme-linked immunosorbent assay (ELISA) [24], latex agglutination assay [25], and immunoblotting [26], which are available from different reference services in Brazil [27]. These tests usually employ crude preparations of the glycoprotein of $43 \mathrm{kDa}$ (GP43) as the primary antigen of P. brasiliensis sensu lato (s.l.) to detect circulating antibodies and have sensitivity between $85 \%$ and $100 \%$ [27]. Concerning serology tests, $P$. lutzii, for instance, has a striking antigenic variation, and since most serologic tests were developed with P. brasiliensis s.l. antigens, P. lutzii-infected hosts may have false-negative results [22].

Early DNA sequencing analyses in the 2000s demonstrated considerable diversity and recognized cryptic entities in Paracoccidioides [28-31]. Therefore, this classification has been revisited several times [32-34]. Presently, it is well known that there are at least four cryptic species included in the P. brasiliensis complex [35-37] and a distantly related group named P. lutzii [35]. There is a recent proposal to elevate agents in the P. brasiliensis complex to species level, where P. brasiliensis sensu stricto (s. str.) is represented by the S1 group (clusters S1a and S1b), and the remaining phylogenetic species are called P. americana (PS2), P. restrepiensis (PS3), and P. venezuelensis (PS4) $[28,36,37]$. The paroxysm of the conflicting organization of the Paracoccidioides genus is the fact that so far, name change relies only on molecular characteristics and usually does not follow phenotypic dissimilarities or the clinical 
pictures of the patients infected with the plurality of Paracoccidioides species. Although such taxonomic modifications may be excessive and could cause a great deal of confusion, there is still a need to revisit the taxonomy using modern approaches such as polyphasic taxonomy [38] or "consilient taxonomy" [39,40]. The availability of sequenced genomes $[41,42]$ enables a new opportunity to consider the Paracoccidioides taxonomy in harmony with other phenotypic, epidemiological, and clinical attributes.

Useful epidemiological surveys are available for Paracoccidioides and reveal that the P. brasiliensis complex members occur in sympatry in a vast South American area. Phylogenetic species S1 (S1a and $\mathrm{S1b}$ ) are the most common PCM agents and are widespread throughout South America, especially in southeastern and southern Brazil, Argentina, and Paraguay. A few cases of the PS2 group have been reported in Venezuela and southeast Brazil. PS3 and PS4 are rare agents of PCM, and isolated cases have been found in Colombia and Venezuela, respectively. Lately, cases related to PS3 have begun to emerge in Colombia, Argentina, Peru, and Brazil [42-44]. The offshoot P. lutzii encompasses a single species. The epicenter of P. lutzii mycosis is in the Midwest and Amazon regions of Brazil, with a single case reported in Ecuador [45,46].

The finding of other species of Paracoccidioides opens new fields for research on the centenarian PCM. Unlike the traditional $P$. brasiliensis, the newly described $P$. lutzii remains enigmatic in many aspects [37,47]. Our group recently initiated the serological study of PCM due to P. lutzii, thus contributing to PCM differentiation by the P. brasiliensis complex and P. lutzii [22]. However, little is known about the antigenic molecules recognized by $P$. brasiliensis/P. lutzii-PCM patient sera, except for the gp43 of P. brasiliensis, which is recognized by all P. brasiliensis-PCM sera [48]. Moreover, no studies have compared the immunogenic antigens recognized between PCM caused by P. brasiliensis s. str. and P. lutzii in humans.

Immunoproteomics is a potentially useful tool to identify disease-associated antigens that elicit immune responses by combining protein separation (2-DE, gel-free separation), immunological detection (immunoblotting), and mass spectrometry or by combining immunocapture and mass spectrometry [49]. Therefore, immunoproteomics effectively provides general diagnostic indications for selecting biomarkers [50] and has been used to analyze several medically relevant microorganisms [51-53]. Here, we propose an experimental immunoproteomics design using antigen preparation derived from the yeast phase of Paracoccidioides species probed against a "gold standard" serum, where for the same patient, we were able to combine fungal isolates identified down to species level by molecular methods and serum of the patient typified by serology (Figure 1). We explored the potential of immunoproteomics to gain insights into the main IgG-reactive molecules in PCM caused by the two main PCM agents, including P. lutzii and P. brasiliensis s. str. Emphasis was given to the $P$. lutzii system since there is still no indication of the main antigenic molecule responsible for antigen-antibody reaction in PCM due to P. lutzii. 


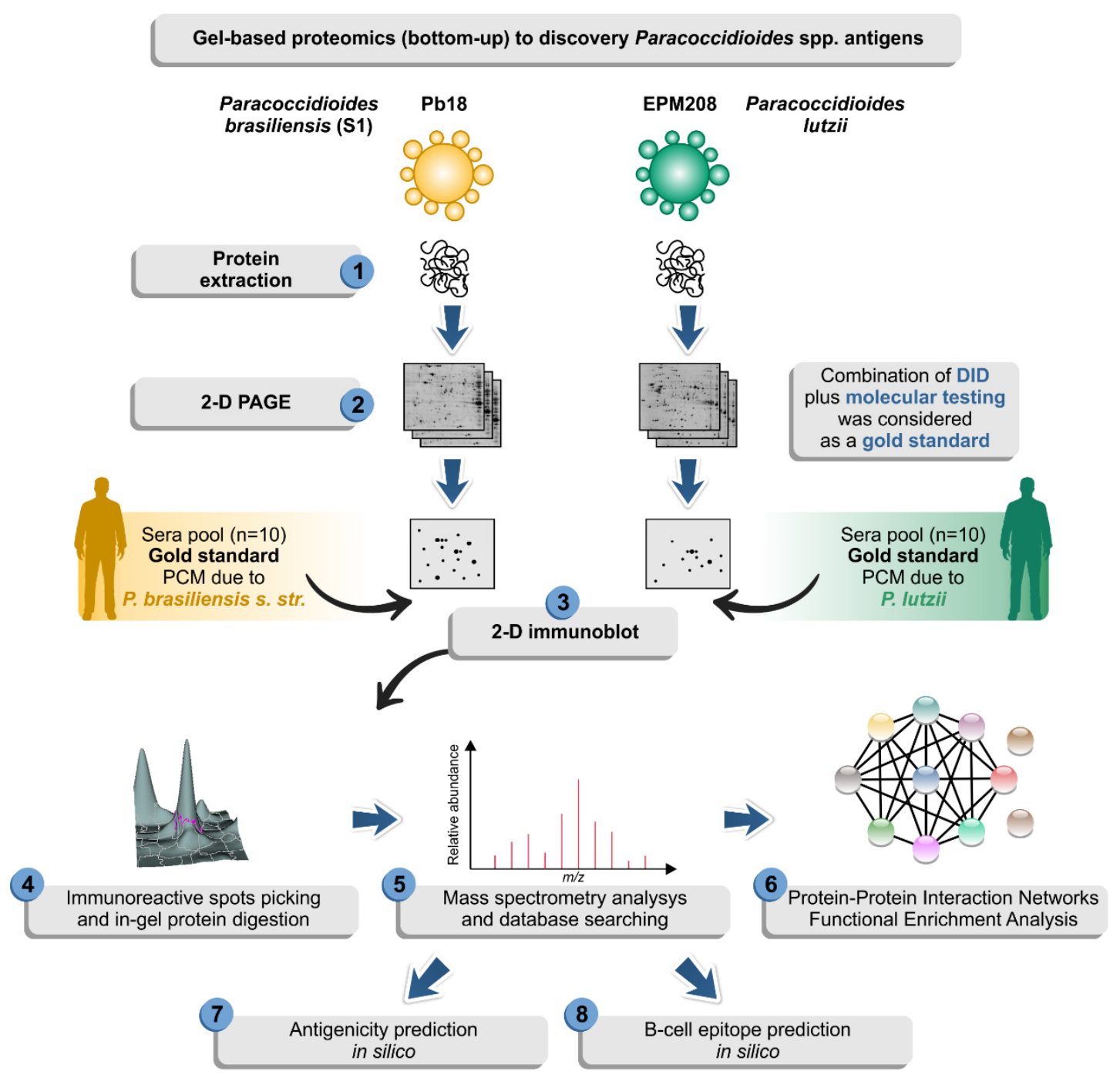

Figure 1. Diagram depicting a two-dimensional (2-D) proteomic approach followed by 2-D immunoblot used in this study in an attempt to identify possible antigens of Paracoccidioides species. The isolate EPM208 of P. lutzii was selected based on previous experiments showing that patients with P. lutzii mycosis show $100 \%$ reactivity with antigenic preparations from this strain [22]. The classical isolate $\mathrm{Pb} 18$ (S1) was used for comparison in the immunoproteomics experiments [54]. Afterward, the yeasts were used to prepare protein extracts (step 1) and then resolved by 2-D gel electrophoresis (step 2). Proteomes were transferred to membranes and probed against sera from patients with confirmed paracoccidioidomycosis (PCM) due to P. lutzii or P. brasiliensis (S1) (step 3). We consider as gold standard serum, the samples that presented positive double immunodiffusion (DID) results and where it was possible to isolate the strain from the patient, following molecular characterization of this isolate. Therefore, only a paired serum: strain was used in the 2-D immunoblot. IgG-reactive proteins (step 4) were identified by mass spectrometry (step 5). Finally, a solid bioinformatic characterization of the immunoreactive protein was employed to highlight potential biomarkers for diagnosis of paracoccidioidomycosis due to $P$. lutzii (steps 6-8).

\section{Materials and Methods}

\subsection{Paracoccidioides Strains and Molecular Characterization}

The Paracoccidioides spp. strains used in this study were the classical EPM208 and Pb18 (EPM16) isolates. Isolates were characterized down to species level by TUB1-RFLP of the alpha-tubulin gene, as described earlier [55]. Attenuation of virulence can occur in some Paracoccidioides isolates when 
subjected to successive in vitro subculturing $[56,57]$ and thus affect the proteome expressed by isolates. Therefore, to avoid any bias among Paracoccidioides spp. isolates at the start of in vitro culturing, isolates were passed through $\mathrm{BALB} / \mathrm{c}$ and then reisolated before protein extraction, as previously described by our group [54].

\subsection{Protein Sample Extraction}

Paracoccidioides yeast cells were grown for 7 days at $36{ }^{\circ} \mathrm{C}$ in biological triplicate in semisolid Fava-Netto medium, and protein extraction was performed as previously described by Rodrigues et al. [58]. Briefly, yeast cells were washed in PBS, centrifuged $\left(5000 \times g, 5 \mathrm{~min}, 4^{\circ} \mathrm{C}\right)$, frozen in liquid nitrogen, and ground in a mortar and pestle until a fine powder was obtained. The powder was suspended in $3 \mathrm{~mL}$ of Tris- $\mathrm{Ca}^{2+}$ buffer $\left(20 \mathrm{mM}\right.$ Tris- $\left.\mathrm{HCl} \mathrm{pH} 8.8,2 \mathrm{mM} \mathrm{CaCl}_{2}\right)$ containing a commercial cocktail of protease inhibitors (1:100) (GE Healthcare, Piscataway, NJ, USA), RNase, and DNase enzymes (1:100) (GE Healthcare, Piscataway, NJ, USA). Then, glass beads (Sigma, St. Louis, MO, USA, $425-600 \mu \mathrm{m}$ ) were added, and the mixture was vigorously vortexed for $30 \mathrm{~min}$ at $4{ }^{\circ} \mathrm{C}$. Cell debris and glass beads were removed by centrifugation $\left(11,000 \times g, 4{ }^{\circ} \mathrm{C}, 10 \mathrm{~min}\right)$, and dithiothreitol $(20 \mathrm{mM})$ was added to the supernatant [59]. Protein concentrations were determined by the Bradford method [60], and the protein extracts were kept at $-70{ }^{\circ} \mathrm{C}$ until use.

\subsection{Two-Dimensional Gel Electrophoresis}

Proteins $(300 \mu \mathrm{g})$ from each replicate were precipitated using the 2D Clean-Up Kit (GE Healthcare, Piscataway, NJ, USA) following the manufacturer's recommendations. Proteins were diluted with rehydration solution (7 M urea, $2 \mathrm{M}$ thiourea, $2 \%$ CHAPS, $1.2 \%$ DeStreak, $2 \% \mathrm{vol} / \mathrm{vol}$ isoelectric focusing (IEF) buffer $\mathrm{pH} 4-7$, and trace bromophenol blue) to a final volume of $250 \mu \mathrm{L}$. IEF was performed using an Ettan IPGphor III system (GE Healthcare, USA). Precast IPG strips (pH 4-7, $13 \mathrm{~cm}$ ) were rehydrated at $30 \mathrm{~V}$ for $12 \mathrm{~h}$. Proteins were focused at $200 \mathrm{~V}$ for $2 \mathrm{~h}, 500 \mathrm{~V}$ for $2 \mathrm{~h}, 1000 \mathrm{~V}$ for $5 \mathrm{~h}$, and then a gradient was applied from 1000 to $5000 \mathrm{~V}$ for $2 \mathrm{~h}$. Finally, the voltage was set to $5000 \mathrm{~V}$ until $60,000 \mathrm{Vhr}$. All IEF experiments were performed at $20^{\circ} \mathrm{C}$. Prior to running the second dimension, the IPG strips were reduced for $15 \mathrm{~min}$ with $1.5 \%$ dithioerythritol and alkylated for $15 \mathrm{~min}$ with $2.5 \%$ iodoacetamide in equilibration buffer (6 M urea, $50 \mathrm{mM}$ Tris- $\mathrm{HCl} \mathrm{pH} 6.8,30 \%$ glycerol, and $2 \%$ SDS). Equilibrated strips were placed on homogeneous $10 \%$ polyacrylamide gels $(16 \mathrm{~cm} \times 16 \mathrm{~cm}$, GE Healthcare, Piscataway, NJ, USA) and sealed with $0.5 \%$ low-melting-point agarose and separated at $10^{\circ} \mathrm{C}$ using a Hoefer SE 600 unit $(15 \mathrm{~mA} /$ gel for $30 \mathrm{~min}$ and then $23 \mathrm{~mA} /$ gel until the dye front reached the bottom of the gel) [58]. Proteins were either developed with silver [61] and Coomassie staining [62] or directly transferred in the case of immunoblot analysis.

\subsection{Naturally Infected Human Serum Samples}

A total of 20 sera from patients with confirmed PCM and 10 self-reported healthy normal donors were used in this investigation. Patients had the chronic form of PCM and exhibited clinical and laboratory signs of the disease, with pulmonary system involvement and mucosal or mucocutaneous lesions [22]. PCM was confirmed in all patients by laboratory demonstration of pathognomonic "ship's wheel" budding yeast cells and fungal isolation in vitro. Therefore, only paired samples (strain: serum) were used as gold standard. Serum samples from patients with PCM due to P. lutzii $(n=10)$ were recovered from the serum bank of the Laboratory of Mycology at the Federal University of Mato Grosso (Cuiabá, Midwest region, Brazil) in 2012-2015, whereas samples from patients with PCM due to P. brasiliensis s. str. (S1; $n=10)$ were retrieved from the serum bank of the Laboratory of Medical and Molecular Mycology at the Federal University of São Paulo (São Paulo state, Southeast region, Brazil) in 2013-2015. Samples were pooled to maximize the recognition of immunoreactive spots and avoid patient-specific effects. The pooled positive reference serum was generated by pooling equal volumes of anti-P. lutzii or anti-P. brasiliensis IgG antibody-positive sera from 10 patients, and the pooled negative reference serum was generated with sera from 10 healthy adult individuals. All serum samples were 
aliquoted and stored at $-70{ }^{\circ} \mathrm{C}$ until use. This study was approved (CAAE: 17177613.6.0000.5541) by the research ethics committee of Federal University of Mato Grosso, and protocol numbers 1796-10 and CEP 3147220120 were approve by the counterpart committee of Federal University of São Paulo. All adult subjects provided informed written consent, and the study was also approved under number 288.250/CEP/HUJM/UFMT.

\subsection{Double Immunodiffusion Assays}

All individual sera were investigated via double immunodiffusion assays (DID) using a P. lutzii cell-free antigen (CFA) preparation derived from the reference isolate EPM208 or the exoantigens from the reference B-339 strain (AgPbB339; PS3) as described earlier [21,22]. A quantitative DID assay was used to establish the titration of each patient's serum. Briefly, $3 \mathrm{~mm}$ of melted $1 \%$ agarose (Sigma A-6877) in PBS was poured onto a glass slide $(75 \mathrm{~mm} \times 25 \mathrm{~mm})$ [22]. This micro-ID test pattern consisted of a central well surrounded by six wells, each $3 \mathrm{~mm}$ in diameter. The central well, located $6 \mathrm{~mm}$ (edge-to-edge) from the other wells, was filled with the antigen solution. Each slide contained two sets of wells. On each slide, the two central wells were filled with $10 \mu \mathrm{L}$ of Paracoccidioides antigen. Slides were incubated overnight in a moist chamber at room temperature $\left(20-25^{\circ} \mathrm{C}\right)$ and then washed for $1 \mathrm{~h}$ in $5 \%$ sodium citrate and $24-48 \mathrm{~h}$ in saline. The slides were dried, stained for 5 min with $0.15 \%$ Coomassie Brilliant blue (Sigma) in ethanol: acetic acid: water $(4: 2: 4 ; \mathrm{v}: \mathrm{v})$, and destained in the solvent mixture alone until precipitin lines were maximally visible. Precipitation bands were noted by visual observation [21].

\subsection{2-D Immunoblot of Paracoccidioides Species Proteins}

For immunoblotting, proteins separated by conventional 2-D gel electrophoresis were electrophoretically transferred onto $0.45 \mu \mathrm{m}$ polyvinylidene difluoride (PVDF) membranes (Bio-Rad, USA) at $25 \mathrm{~V}$ for $1 \mathrm{~h}$ with transfer buffer ( $25 \mathrm{mM}$ Tris base, $192 \mathrm{mM}$ glycine, $20 \%$ methanol; $\mathrm{pH}$ 8.3) [63] using a Trans-Blot SD semidry transfer cell (Bio-Rad, Rockville, MD, USA). The success of electrotransfer was evaluated by Ponceau S staining $(0.15 \%$ Ponceau $S$ and $1 \%$ acetic acid $(\mathrm{v} / \mathrm{v}))$ staining. Membranes were destained and then free binding sites were blocked overnight in PBS blocking buffer (1\% bovine serum albumin, supplemented with $0.05 \%(\mathrm{v} / \mathrm{v})$ Tween 20 and 5\% (wt/vol) skim milk, pH 7.6) at $4{ }^{\circ} \mathrm{C}[64]$.

Membranes were probed with primary antibody diluted 1:500 (gold standard pooled human sera) at $25^{\circ} \mathrm{C}$ for $2 \mathrm{~h}$. Afterward, the membranes were washed three times with Tris-buffered saline (pH 7.5) containing $0.05 \%(\mathrm{v} / \mathrm{v})$ Tween 20 (TBST) for $10 \mathrm{~min}$ and incubated with horseradish peroxidase (HRP)-conjugated goat anti-human IgG (1:1000 dilution) for $2 \mathrm{~h}$ at room temperature. The membranes were then washed with TBST, and the signal was detected with an enhanced chemiluminescence detection kit (GE Healthcare, Uppsala, Sweden). Immunoblots were imaged in a transilluminator (Uvitec, Cambridge). Alliance software v. 4.7 was used to capture several images at different exposure times, reaching 10 shots with a $2 \mathrm{~s}$ increment.

\subsection{Identification of Immunoreactive Proteins by MALDI-ToF MS/MS Analysis}

Fresh Coomassie-stained protein spots matching 2-D immunoblot immunoreactive spots were manually excised and processed by MALDI-ToF/MS. Spots were washed in ultrapure water, destained in $50 \mathrm{mM}$ ammonium bicarbonate ( $\mathrm{pH} 8.0$ ) with $50 \%$ acetonitrile (ACN), shrunk with $100 \%$ acetonitrile, and vacuum dried. Next, the gel pieces were incubated with $12.5 \mathrm{ng} / \mu \mathrm{L}$ of sequencing grade trypsin (Promega, Madison, WI, USA) overnight at $37^{\circ} \mathrm{C}$. After trypsin digestion, the supernatants were separated, and the peptides extracted first into $0.5 \%$ trifluoroacetic acid $/ 50 \%$ acetonitrile and then into $100 \%$ ACN. All extracts were pooled, and the volume was reduced by SpeedVac [58].

Following trypsin digestion, the peptide suspension derived for each spot was spotted on a MALDI target plate, mixed with the matrix $\alpha$-cyano-4-hydroxy-trans-cinnamic acid (Sigma), and allowed to air dry at room temperature. The samples were analyzed with an AB SCIEX TOF/TOF 5800 mass 
spectrometer (Applied Biosystems, Foster City, CA, USA) in automated mode. Initially, a MALDI MS spectrum was acquired for each spot (800 shots/spectrum), and peaks with a signal-to-noise ratio greater than 50 in at least two consecutive fractions until a maximum of 10 precursors per fraction were automatically selected for MS/MS analysis (at least 2200 shots/spectrum) using collision energy of $1 \mathrm{keV}$ with air as the collision gas. All mass spectra were calibrated using the Mass Standards Kit for Calibration of AB SCIEX TOF/TOF (Applied Biosystems, Foster City, CA, USA) [58]. The spectra were searched against an in-house database constructed with genome information using two reference strains of P. brasiliensis s.l. ( $\mathrm{Pb} 03$, accession number ABHV00000000; Pb18, accession number ABKI00000000) and one strain of P. lutzii (Pb01; accession number ABKH00000000) [65] as selection criteria and the Paragon algorithm in the Protein Pilot software (Applied Biosystems, Foster City, CA, USA). A false discovery rate of $1 \%$ was applied, and only peptides with $>95 \%$ confidence were listed.

\subsection{Bioinformatics Analysis}

The Search Tool for the Retrieval of Interacting Genes/Proteins (STRING) (version 11) [66] was used to construct a protein interaction network (experimentally verified as well as predicted) of the immunoreactive proteins in the P. brasiliensis and P. lutzii immunoproteomes. Since most biological information is available for Paracoccidioides brasiliensis, it was used as a model organism in both analyses. In addition, the Kyoto Encyclopedia of Genes and Genomes (KEGG) pathway analysis [67], implemented in the STRING database, was used to ascertain the function of the identified proteins. The web application iPath3.0 was used to visualize and analyze cellular pathways enriched in STRING analysis (KEGG pathway analysis) [68]. WoLF PSORT was used for predicting subcellular protein localization of the immunoreactive proteins based on their amino acid sequences [69]. The InteractiVenn software (unions by list) [66] was used to generate Venn diagrams for our list of immunoreactive proteins, as well as to compare the dataset found in this study with those immunoreactive proteins published for human PCM [70] and murine PCM [71].

High-throughput in silico prediction of protein antigenicity was used to compare B-cell epitopes between P. brasiliensis ( $\mathrm{Pb} 18)$ and P. lutzii ( $\mathrm{Pb} 01)$ immunoreactive proteins. Protein sequences were retrieved from NCBI and submitted to ABCpred [72], BepiPred [73], and COBEpro [74] using the default parameters. AntigenPRO [74] and VaxiJen v2.0 [75], two sequence-based, alignment-free and pathogen-independent predictors of protein antigenicity, were used to predict full-length protein antigenicity with a prediction threshold of 0.5 . Therefore, proteins having antigenic scores $>0.5$ were considered to be antigenic.

Potential biomarkers for PCM immunodiagnostics were submitted to the ConSurf server [76] to estimate the evolutionary conservation of amino acid residue positions based on the phylogenetic relations between homologous sequences. Multiple sequence alignment was achieved using MAFFT [77], and the homologs were collected from UNIREF90 [78] using the homolog search algorithm HMMER (HMMER E-value: 0.0001, number of HMMER iterations: 1, maximal \%ID between sequences: 95; minimal \%ID for homologs: 35) [79]. The degree to which an amino acid position is evolutionarily conserved (i.e., its evolutionary rate) is highly dependent on its structural and functional importance and was compared with predicted B-cell epitopes. The continuous conservation scores were partitioned into a discrete scale of 9 bins for visualization, where bin 9 contained the most conserved positions, and bin 1 had the most variable positions [76].

Finally, for modeling the protein's 3D molecular structures of Paracoccidioides antigens, the amino acid sequences were retrieved from NCBI and submitted to RaptorX [80], a web server for protein structure-function prediction. Protein 3D molecular structures, including molecular surface and inspection of molecular structures, were determined using the 3D Molecule Viewer implemented in the CLC Genomics Workbench v.9.0.1. In the last step of the homology modeling, the model's refined structure was subjected to a series of tests to check its internal consistency and reliability. Backbone conformation was evaluated by examining the Psi/Phi Ramachandran plot obtained from PROCHECK 
analysis [81]. We considered a model to have good quality when over $90 \%$ of the amino acid residues were located in the most favored regions [81].

\section{Results}

\subsection{Protein Profile of Paracoccidioides Species}

Protein extraction using whole yeast cells yielded around $3 \mathrm{mg}$ of proteins and the proteins integrity was observed by 1D SDS-PAGE. Whole-cell lysates $(300 \mu \mathrm{g})$ from P. lutzii and P. brasiliensis were fractionated by 2-D electrophoresis, using an immobilized $\mathrm{pH}$ gradient of $4-7$, which provided better sample separation and improved resolution (Figure 2a,c).
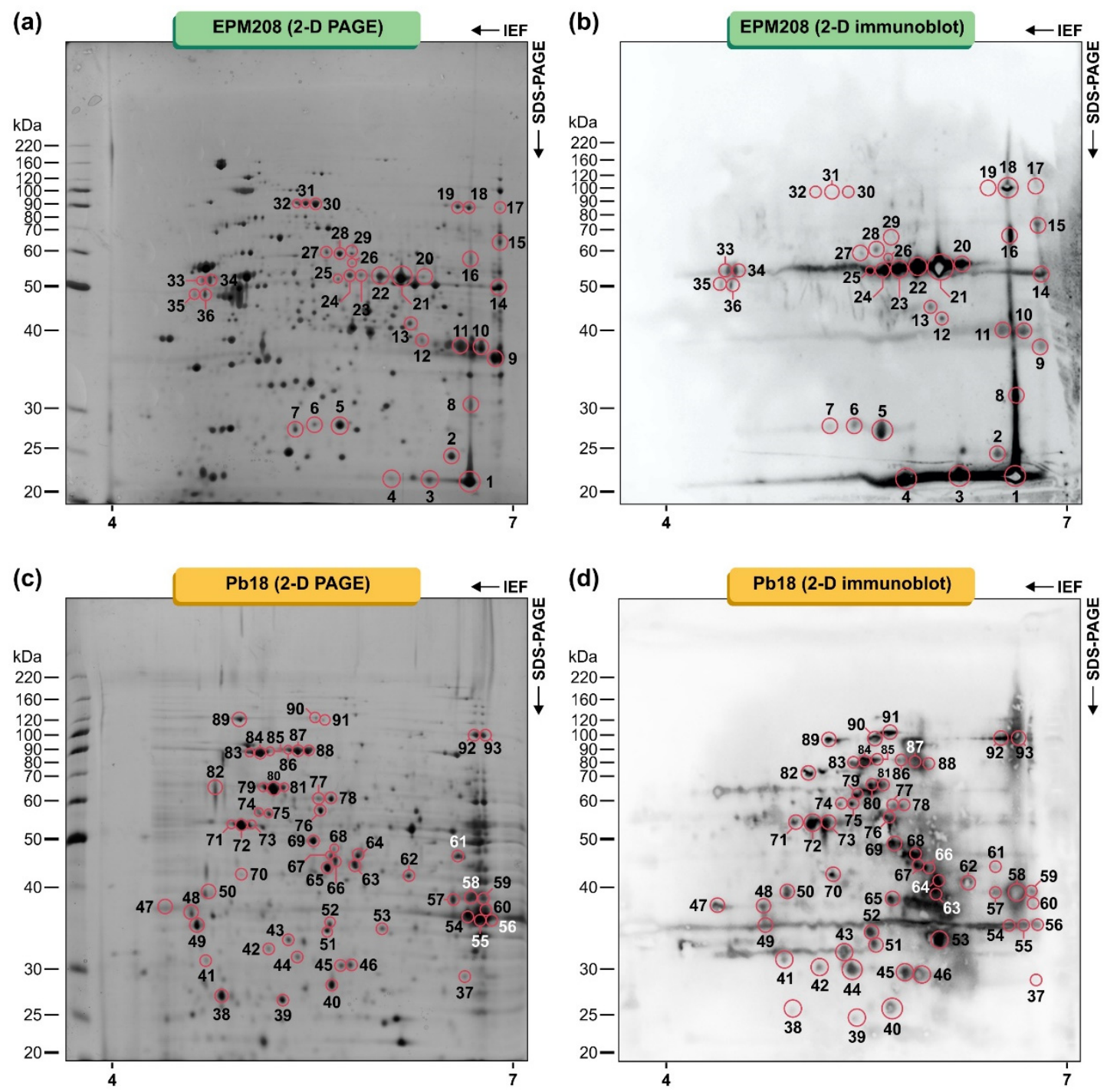

Figure 2. Proteins from Paracoccidioides lutzii (EPM208) and Paracoccidioides brasiliensis (Pb18) were fractionated using $13 \mathrm{~cm} \mathrm{pH} \mathrm{4-7} \mathrm{(left} \mathrm{to} \mathrm{right)} \mathrm{strips} \mathrm{in} \mathrm{the} \mathrm{first} \mathrm{dimension} \mathrm{and} \mathrm{10 \%} \mathrm{SDS-PAGE} \mathrm{gels} \mathrm{in}$ the second dimension, developed by silver staining. (a) 2-D PAGE of EPM208, (b) 2-D immunoblot using a pool of sera of patients $(n=10)$ with PCM due to P. lutzii, (c) 2-D PAGE of Pb18, and (d) 2-D immunoblot using a serum pool of patients $(n=10)$ with PCM due to P. brasiliensis s. str. (S1). Data are representative of three independent experiments. Molecular masses of standard proteins are given on the gels' left side (BenchMark Protein Ladder, Invitrogen, Waltham, MA, USA). The spots recognized by sera from patients with PCM and submitted to MALDI-ToF mass spectrometry analysis (MS/MS) are highlighted. The numbers refer to the spot identification used in Tables 1 and 2. 
Table 1. Identification of IgG-reactive proteins recognized by sera of patients with paracoccidioidomycosis due to Paracoccidioides lutzii.

\begin{tabular}{|c|c|c|c|c|c|c|c|}
\hline Spot Number & Accession Number & Gene Name & Protein Name & Mass (Mr) & pI & Cov. $(\%)$ & Score \\
\hline P101, P103, P104 & XP_015702763 & PADG_07749 & NAD(P)H: quinone oxidoreductase, type IV & 23,585 & 6.21 & 16 & 228 \\
\hline Pl02 & XP_015700719 & PADG_02764 & Uncharacterized protein (Thioredoxin-like Superfamily) & 30,945 & 8.45 & 14 & 124 \\
\hline P105 & XP_002795879 & PADG_06906 & Triosephosphate isomerase & 27,159 & 5.39 & 24 & 408 \\
\hline P106 & XP_002797384 & PADG_03581 & Phenylacetone monooxygenase & 68,182 & 5.95 & 1 & 33 \\
\hline P107 & XP_015701261 & PADG_00322 & Uncharacterized protein (PRTases type I Superfamily) & 23,117 & 5.28 & 22 & 186 \\
\hline $\mathrm{P} 108$ & XP_002797532 & PADG_07190 & Proteasome subunit alpha & 29,747 & 6.36 & 3 & 39 \\
\hline Pl09, P110 & Q8X1X3 & PADG_02411 & Glyceraldehyde-3-Phosphate dehydrogenase & 36,619 & 8.26 & 10 & 185 \\
\hline Pl11 & XP_002796107 & PADG_00668 & Fructose-bisphosphate aldolase 1 & 39,721 & 6.09 & 18 & 429 \\
\hline Pl12 & XP_002791734 & PADG_01372 & Mannitol-1-Phosphate 5-dehydrogenase & 43,119 & 5.66 & 3 & 78 \\
\hline Pl13, Pl30, Pl31, Pl32 & XP_002790117 & PADG_08118 & HSP72-like protein & 70,919 & 5.08 & 9 & 390 \\
\hline Pl14 & XP_002793640 & PADG_04710 & Citrate synthase & 51,516 & 9.02 & 16 & 307 \\
\hline Pl16 & XP_002791040 & PADG_01483 & Isocitrate lyase & 60,173 & 6.79 & 2 & 26 \\
\hline Pl17, P119 & XP_002793534 & PADG_04604 & Transketolase & 74,940 & 5.97 & 2 & 28 \\
\hline Pl20, Pl21, Pl22, Pl23, Pl24, Pl34 & XP_015703472 & PADG_04059 & Enolase & 48,515 & 5.49 & 19 & 389 \\
\hline Pl27, Pl28, Pl29 & XP_002789992 & PADG_08369 & HSP60, mitochondrial & 62,266 & 5.51 & 13 & 510 \\
\hline Pl36 & XP_002797075 & PADG_03893 & Uncharacterized protein & 38,092 & 8.46 & 3 & 26 \\
\hline
\end{tabular}


Table 2. Identification of IgG-reactive proteins recognized by sera of patients with paracoccidioidomycosis due to Paracoccidioides brasiliensis sensu stricto.

\begin{tabular}{|c|c|c|c|c|c|c|c|}
\hline Spot Number & Accession Number & Gene Name & Protein & Mass (Mr) & pI & Cov. $(\%)$ & Score \\
\hline $\mathrm{Pb} 37$ & XP_010762888 & PADG_07524 & Nucleoside diphosphate kinase & 16,908 & 6.84 & 23 & 226 \\
\hline $\mathrm{Pb} 38, \mathrm{~Pb} 40, \mathrm{~Pb} 41, \mathrm{~Pb} 44$ & XP_010758730 & PADG_03095 & 1-Cys peroxiredoxin $(\mathrm{PbPrx} 1)$ & 24,931 & 5.28 & 17 & 175 \\
\hline $\mathrm{Pb} 45$ & XP_010763035 & PADG_07782 & Deoxyuridine 5'-triphosphate nucleotidohydrolase & 22,190 & 5.27 & 12 & 75 \\
\hline $\mathrm{Pb} 46$ & XP_010762134 & PADG_06906 & Triosephosphate isomerase & 27,176 & 5.39 & 10 & 66 \\
\hline $\mathrm{Pb} 48$ & XP_010759909 & PADG_11679 & Proliferating cell nuclear antigen & 36,276 & 4.87 & 11 & 205 \\
\hline $\mathrm{Pb} 49$ & XP_010759842 & PADG_04440 & Uncharacterized protein (14-3-3 Superfamily) & 29,738 & 4.68 & 24 & 322 \\
\hline $\mathrm{Pb} 50$ & XP_010759301 & PADG_04056 & 14-3-3 family protein epsilon & 32,531 & 4.74 & 19 & 240 \\
\hline $\mathrm{Pb} 52$ & XP_010760066 & PADG_04603 & Spermidine synthase & 33,714 & 5.33 & 8 & 220 \\
\hline $\mathrm{Pb} 53$ & XP_010759656 & PADG_03943 & Phosphomannomutase & 30,560 & 5.6 & 5 & 33 \\
\hline Pb54, Pb55, Pb56 & XP_010758444 & PADG_02411 & Glyceraldehyde-3-phosphate dehydrogenase & 37,397 & 7.12 & 12 & 232 \\
\hline Pb57, Pb58, Pb59, Pb60 & XP_010756450 & PADG_00668 & Fructose-bisphosphate aldolase 1 & 39,764 & 6.28 & 14 & 391 \\
\hline $\mathrm{Pb} 62, \mathrm{~Pb} 70$ & XP_010763814 & PADG_08468 & 4-hydroxyphenylpyruvate dioxygenase & 45,844 & 5.64 & 3 & 37 \\
\hline $\mathrm{Pb} 65$ & XP_010761900 & PADG_06488 & Uncharacterized protein (cyclophilin superfamily) & 41,276 & 5.42 & 15 & 352 \\
\hline Pb66, Pb68, Pb69, Pb83, Pb84, Pb85 & XP_010763478 & PADG_08118 & HSP72-like protein & 70,949 & 5.08 & 14 & 513 \\
\hline $\mathrm{Pb} 67$ & XP_010756960 & PADG_01551 & Thioredoxin reductase & 38,134 & 5.42 & 7 & 83 \\
\hline $\mathrm{Pb} 71, \mathrm{~Pb} 72, \mathrm{~Pb} 73$ & XP_010763627 & PADG_08349 & ATP synthase subunit beta & 66,837 & 6.01 & 12 & 423 \\
\hline $\mathrm{Pb} 74$ & XP_010763342 & PADG_07950 & Hexokinase & 55,065 & 5.19 & 13 & 224 \\
\hline $\mathrm{Pb} 75$ & XP_010758595 & PADG_02761 & HSP75-like protein & 67,330 & 5.27 & 9 & 446 \\
\hline $\mathrm{Pb} 76$ & XP_010761260 & PADG_05922 & Uncharacterized protein (M20_dimer domain-containing protein) & 63,634 & 6.36 & 6 & 145 \\
\hline $\mathrm{Pb} 78$ & XP_010762465 & PADG_07213 & Acetyltransferase component of pyruvate dehydrogenase complex & 55,658 & 7.67 & 3 & 93 \\
\hline $\mathrm{Pb} 79, \mathrm{~Pb} 80, \mathrm{~Pb} 81$ & XP_010763632 & PADG_08369 & HSP60, mitochondrial & 62,522 & 5.51 & 16 & 797 \\
\hline $\mathrm{Pb} 82, \mathrm{~Pb} 87$ & XP_010759621 & PADG_03841 & Protein disulfide isomerase & 58,878 & 4.88 & 15 & 498 \\
\hline $\mathrm{Pb} 86, \mathrm{~Pb} 88$ & XP_010756347 & PADG_00430 & HSP7-like protein & 94,608 & 6.4 & 8 & 393 \\
\hline $\mathrm{Pb} 89, \mathrm{~Pb} 90$ & XP_010758132 & PADG_02785 & $\begin{array}{l}\text { Uncharacterized protein (NBD sugar kinase HSP70 actin } \\
\text { superfamily) }\end{array}$ & 80,759 & 4.91 & 9 & 205 \\
\hline $\mathrm{Pb} 92, \mathrm{~Pb} 93$ & XP_010760563 & PADG_11845 & Aconitate hydratase, mitochondrial & 80,073 & 6.46 & 8 & 136 \\
\hline
\end{tabular}




\subsection{Profiling the Humoral Response in Human PCM}

All sera used in this study were typified by immunodiffusion using the AgPbB339 reference exoantigen or EPM208 cell-free antigen, as previously described [22]. Sera of patients from São Paulo were reactive to the classical antigen AgPbB339, with titration varying between 1:4 and 1:64 (Supplementary Figure S1a). The molecular identification of the isolates by TUB1-RFLP revealed they belong to the $\mathrm{S} 1$ group (P. brasiliensis $s$. str.). On the other hand, a positive reaction was detected for sera from patients living in the Brazilian Midwest using the EPM208 CFA preparation, with titration varying between 1:4 and 1:32 (Supplementary Figure S1b), showing a strong identity with P. lutzii. Likewise, the isolates from Mato Grosso were classified as P. lutzii by TUB1-RFLP, confirming the serological data. Sera from the healthy normal donors did not react with AgPbB339 or EPM208 CFA preparation (Supplementary Figure S1).

Afterward, typified sera were used in two-dimensional immunoblot tests, revealing a total of 93 IgG-reactive spots in the proteome of Paracoccidioides species (Figure 2). Thirty-six spots with molecular weights (MW) ranging from 23 to $74 \mathrm{kDa}$ and with isoelectric points in the range from 5.08 to 9.02 were strongly detected in the P. lutzii proteome using the pooled human serum of patients with PCM due to P. lutzii (gold standard; Figure 2b). The immunoproteome of P. brasiliensis was much more diverse than that of P. lutzii, and 57 spots with molecular weights (MW) ranging from 16.9 to $94.6 \mathrm{kDa}$ and with isoelectric points in the range from 4.68 to 7.67 were strongly detected in the pooled human serum of patients with PCM due to P. brasiliensis s. str. (gold standard; Figure 2d). Moreover, no significant IgG binding reactivity was detected with the sera from healthy subjects.

\subsection{IgG-Reactive Protein Identification by Mass Spectrometry}

A total of 93 spots matching the immunoreactive proteins described above were excised from fresh 2-D Coomassie-stained gels and submitted to mass spectrometry analysis (MS/MS). Homology database search with the Mascot search engine allowed identifying 77 immunoreactive spots corresponding to 16 proteins in the P. lutzii proteome (Table 1) and 25 proteins in the P. brasiliensis proteome (Table 2). Interestingly, several spots showed two or more isoforms, such as $\mathrm{NAD}(\mathrm{P}) \mathrm{H}$ :quinone oxidoreductase, type IV (spots \# P101, P103, and P104); glyceraldehyde-3-phosphate dehydrogenase (spots \# P109 and Pl10), HSP72-like protein (spots \# Pl13, Pl30, Pl31, and Pl32), transketolase (spots \# Pl17 and Pl19), and enolase (spots \# Pl20, Pl21, Pl22, Pl23, Pl24 and Pl34). Three uncharacterized proteins were detected for the first time in the P. lutzii immunoproteome and four were detected for the first time in the $P$. brasiliensis immunoproteome. Surprisingly, we did not identify any isoforms of the glycoprotein of 43,000 Da (gp43) in the immunoproteome of P. lutzii or P. brasiliensis. However, this molecule has been reported as the immunodominant antigen in PCM patients infected with members of the P. brasiliensis complex. Only five proteins were found to be shared between P. lutzii and P. brasiliensis immunoproteomes (i.e., triosephosphate isomerase, glyceraldehyde-3-phosphate dehydrogenase, fructose-bisphosphate aldolase 1, HSP72-like protein, and HSP60, mitochondrial) (Figure 3a), and three of them were previously described in PCM (Figure 3b). A comparison between our dataset and previous immunogenic proteins reported for murine PCM revealed a remarkable difference between human and murine immunogenic proteins. Only four proteins were found to be common between the systems (Figure 3c).

\subsection{STRING Analysis of Paracoccidioides Immunoproteome}

To further understand the properties and correlation of immunogenic proteins, the 16 antigens of $P$. lutzii were used to generate a protein-protein interaction network $\left(p=4.33 \times 10^{-15}\right.$; average node degree: 3.12; Figure 4a) and visualize the most representative classes of these proteins for KEGG pathways (depicted in Figure $4 \mathrm{~b}$ ). The P. lutzii immunogenic proteins represented a broad range of biological functions, including biosynthesis of secondary metabolites $\left(n=8\right.$; FDR $=2.29 \times 10^{-7}$; map01110), carbon metabolism $\left(n=7 ; \mathrm{FDR}=8.22 \times 10^{-9}\right.$; map01200), metabolic pathways $(n=7$; 
FDR $=0.00054 ;$ map01100), biosynthesis of amino acids $\left(n=6 ; \mathrm{FDR}=2.29 \times 10^{-7} ;\right.$ map01230), biosynthesis of antibiotics ( $n=6$; FDR $=6.96 \times 10^{-6}$; map01130), glycolysis/gluconeogenesis $(n=4$; FDR $=2.95 \times 10^{-6} ;$ map00010 $)$, fructose and mannose metabolism $\left(n=3 ; \mathrm{FDR}=4.02 \times 10^{-5} ;\right.$ map00051), methane metabolism $(n=2 ; \mathrm{FDR}=0.0018$; map00680), pentose phosphate pathway $(n=2 ; \mathrm{FDR}=0.0021$; map00030), glyoxylate and dicarboxylate metabolism $(n=2 ; \mathrm{FDR}=0.0037$; map00630), and RNA degradation $(n=2$; FDR $=0.0068$; map03018) (Figure $4 b)$. The protein-protein interaction network showed that seven proteins that are mainly involved in carbon metabolism, biosynthesis of secondary metabolites, and metabolic pathways could interact with each other. The three uncharacterized proteins (XP_015700719, XP_015701261, and XP_002797075) are described as newly identified antigens, and along with $\mathrm{NAD}(\mathrm{P}) \mathrm{H}$ :quinone oxidoreductase, type $\mathrm{IV}$, phenylacetone monooxygenase, proteasome subunit alpha, and mannitol-1-phosphate 5-dehydrogenase showed no relationship with others (Figure 4).

(a)

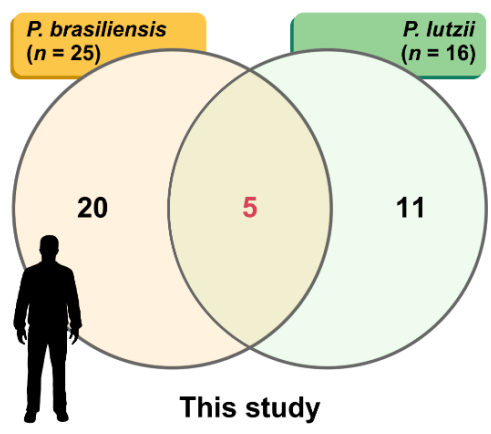

(b)

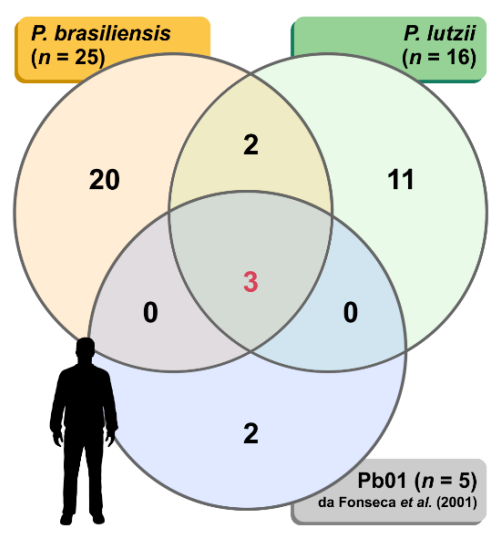

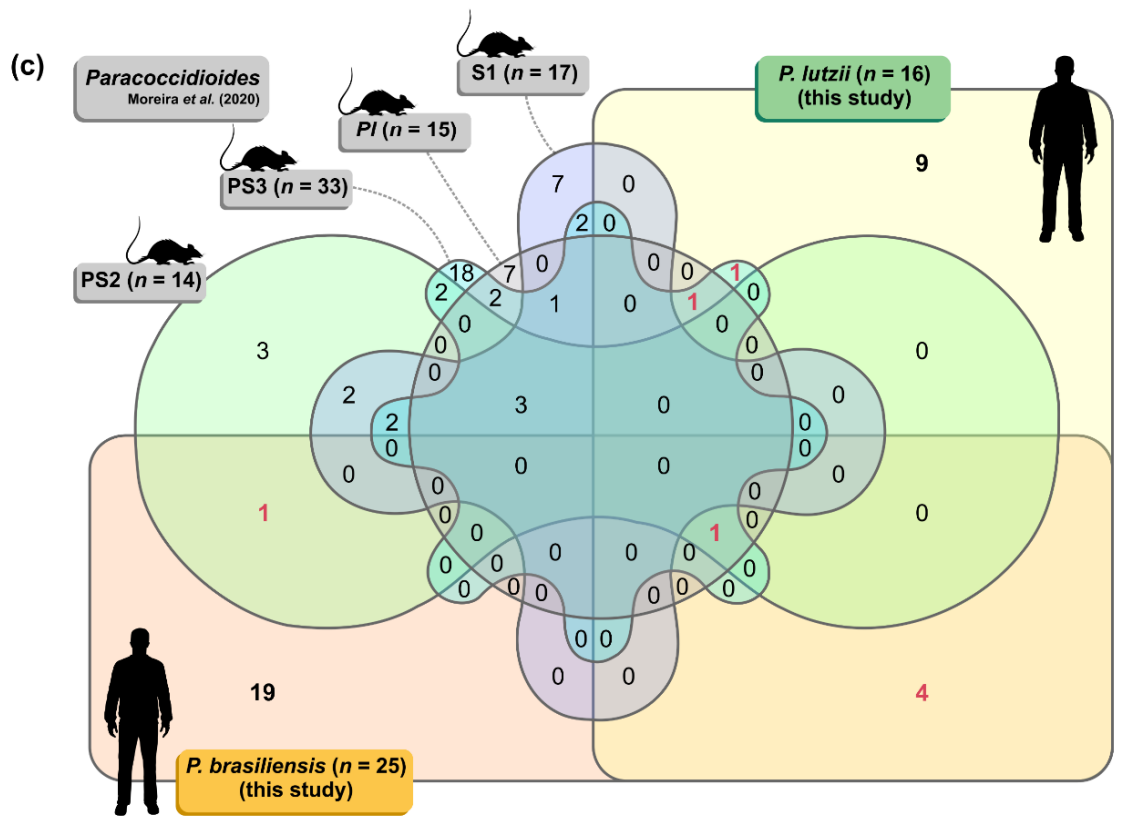

Figure 3. (a) The Venn diagram summarizes the number of proteins identified in the P. lutzii $(n=16)$ and P. brasiliensis $(n=25)$ proteomes. (b) The three-way Venn diagram summarizes the number of proteins in each combination found in this study (P. lutzii and P. brasiliensis) shared with the immunoproteome published by da Fonseca et al. [70] for human PCM ( $n=5$ immunoreactive proteins). (c) The six-way Venn diagram summarizes the number of proteins in each combination found in this study (P. lutzii and P. brasiliensis) shared with the immunoproteomes published by Moreira et al. [71] for murine PCM using $P$. brasiliensis s. str. (S1; $n=17$ immunoreactive proteins), P. americana (PS2; $n=14$ immunoreactive proteins), $P$. restrepiensis (PS3; $n=33$ immunoreactive proteins), and $P$. lutzii ( $n=15$ immunoreactive proteins). Shared proteins are highlighted in red. 

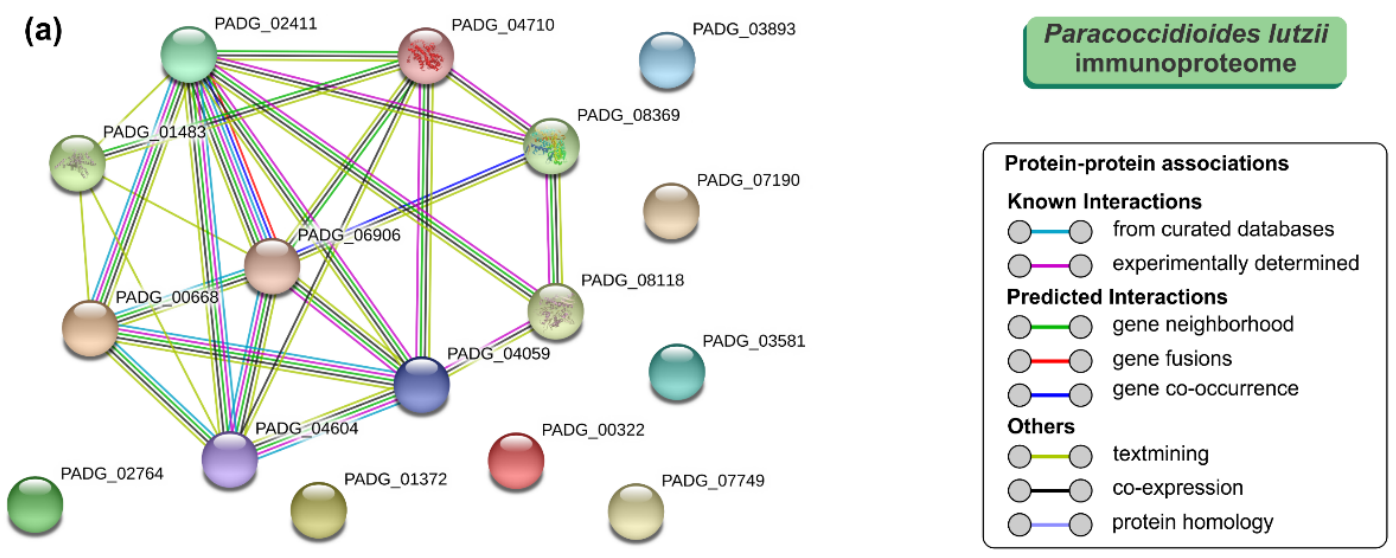

(b)

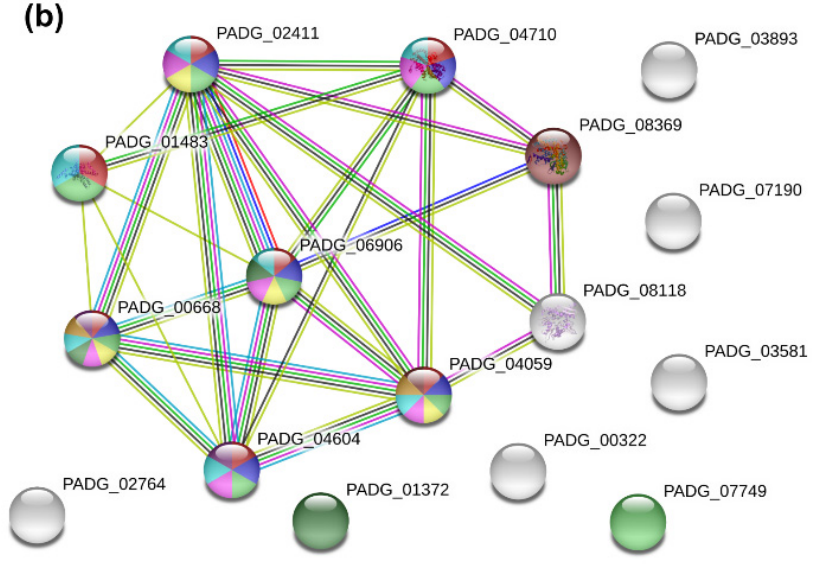

\begin{tabular}{|lll|}
\hline KEGG Pathways \\
& Pathway & Description \\
(7) & map01200 & Carbon metabolism \\
6) & map01230 & Biosynthesis of amino acids \\
(8) & map01110 & Biosynthesis of secondary metabolites \\
(4) & map00010 & Glycolysis / Gluconeogenesis \\
6) & map01130 & Biosynthesis of antibiotics \\
(3) & map00051 & Fructose and mannose metabolism \\
(7) & map01100 & Metabolic pathways \\
(2) & map00680 & Methane metabolism \\
(2) & map00030 & Pentose phosphate pathway \\
(2) & map03018 & RNA degradation \\
\hline
\end{tabular}

Figure 4. The Search Tool for the Retrieval of Interacting Genes/Proteins (STRING) analysis of Paracoccidioides lutzii immunoproteome. (a) A total of 16 immunoreactive proteins from P. lutzii were used as input for STRING analysis, and a network was built based on high confidence evidence from experimental protein-protein interaction (purple line) and curated (light blue lines) databases. Proteins are indicated by nodes labeled with the encoding gene symbol (number of edges $=25$ ) from P. brasiliensis as a model. (b) Classification of proteins based on the Kyoto Encyclopedia of Genes and Genomes (KEGG) pathways. Protein-protein interactions' enrichment $p$-value $=4.33 \times 10^{-15}$.

As we expected, the protein-protein interaction network in STRING for the 25 immunoreactive proteins of $P$. brasiliensis had higher node degrees $\left(p<1.0 \times 10^{-16}\right.$; average node degree: 4.72; Figure 5a). The most representative classes of these proteins for KEGG pathways are shown in Figure 5b. Likewise, the $P$. brasiliensis immunogenic proteins covered an extensive range of biological functions, including metabolic pathways $\left(n=13\right.$; FDR $=9.58 \times 10^{-7}$; map01100), biosynthesis of antibiotics $(n=8$; FDR $=1.56 \times 10^{-6}$; map01130), biosynthesis of secondary metabolites $\left(n=8 ;\right.$ FDR $=8.33 \times 10^{-6}$; map01110), carbon metabolism $\left(n=6 ; \mathrm{FDR}=3.94 \times 10^{-6}\right.$; map01200), glycolysis/gluconeogenesis $(n=5$; FDR $=1.34 \times 10^{-6} ;$ map00010), fructose and mannose metabolism $\left(n=4 ; \mathrm{FDR}=5.72 \times 10^{-6} ;\right.$ map00051), biosynthesis of amino acids $(n=4$; FDR $=0.0013$; map01230), protein processing in endoplasmic reticulum $(n=3 ;$ FDR $=0.0060 ;$ map04141), RNA degradation $(n=2 ;$ FDR $=0.0262 ;$ map03018), and MAPK signaling pathway-yeast $(n=2 ; \mathrm{FDR}=0.0311$; map04011) (Figure $5 \mathrm{~b})$. The protein-protein interaction network showed that 22 proteins, mainly involved in metabolic pathways, biosynthesis of secondary metabolites, biosynthesis of antibiotics, and carbon metabolism, could interact with each other. Two uncharacterized proteins (XP_010761900 and XP_010758132), described here as newly identified antigens, interacted with each other as well as with proteins related to protein processing in the endoplasmic reticulum and RNA degradation. A newly identified 1-Cys peroxiredoxin 
(PbPrx1, XP_010758730) and an uncharacterized protein (XP_010759842) showed interactions with proteins related to the protein processing in the endoplasmic reticulum (e.g., HSP72-like protein and protein disulfide-isomerase). Three proteins, named, spermidine synthase, 4-hydroxyphenylpyruvate dioxygenase, and an uncharacterized protein (XP_010761260, M20_dimer domain-containing protein) showed no relationship with the others (Figure 5).

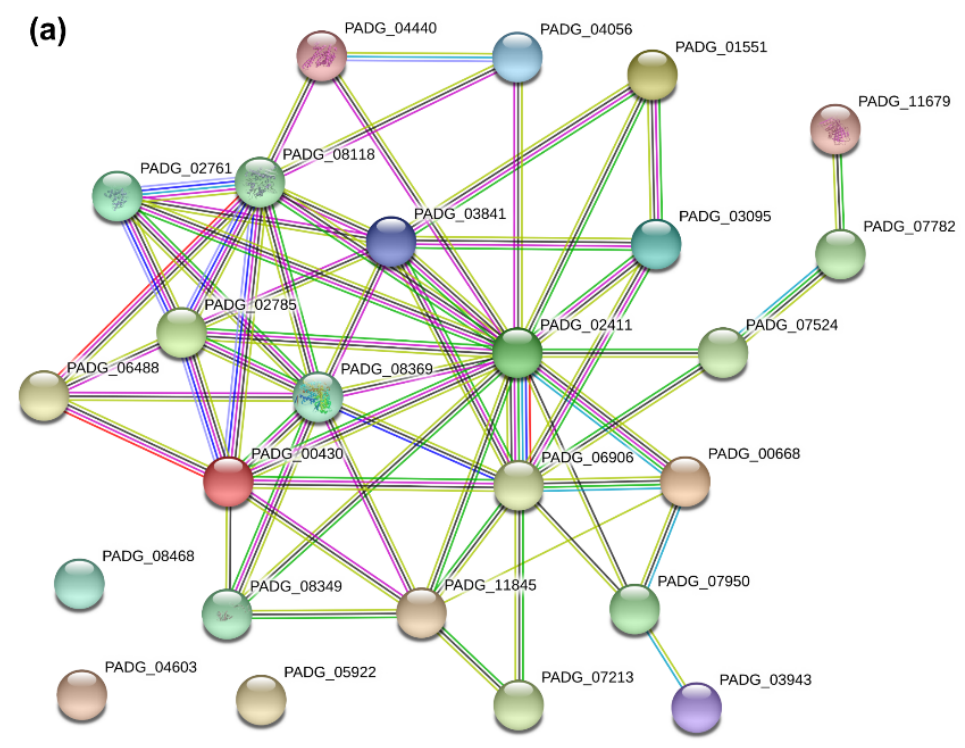

Protein-protein associations
Predicted Interactions
Others Interactions
gene neighborhood

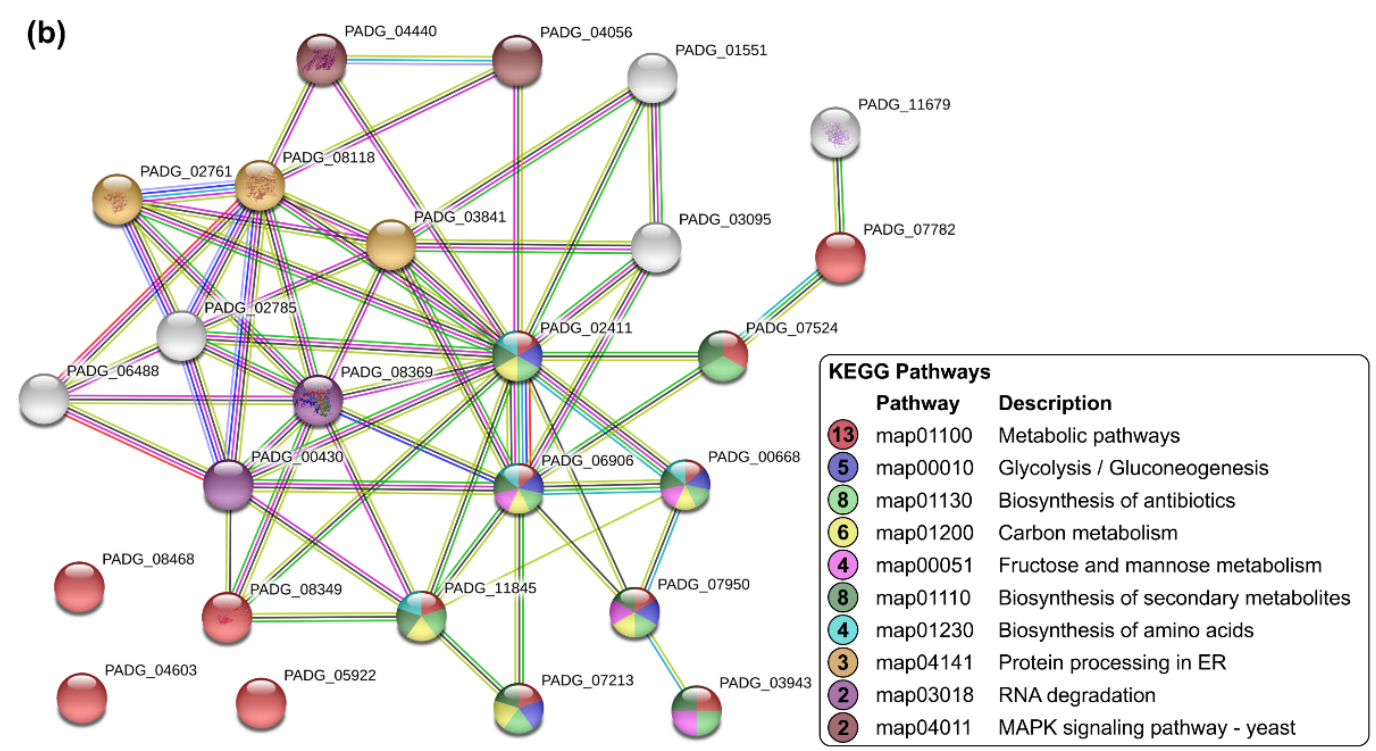

Figure 5. STRING analysis of Paracoccidioides brasiliensis immunoproteome. (a) A total of 25 immunoreactive proteins from $P$. brasiliensis were used as input for STRING analysis, and a network was built based on high confidence evidence from experimental protein-protein interaction (purple line) and curated (light blue lines) databases. Proteins are indicated by nodes labeled with the encoding gene symbol (number of edges $=25$ ) from P. brasiliensis as a model. (b) Classification of proteins based on KEGG pathways. Protein-protein interactions' enrichment $p$-value $<1.0 \times 10^{-16}$.

\subsection{Immunoinformatic Analysis of Paracoccidioides Antigens}

Bioinformatic analyses were used to predict subcellular localization of immunoreactive proteins. Results showed 20 cytoplasmic (55.6\%), followed by 13 mitochondrial $(36.1 \%)$, two nuclear $(5.6 \%)$, and one extracellular localization (2.7\%) (Table 3). 
Table 3. Characterization of full-length immunoreactive proteins of Paracoccidioides spp., for predicted antigenicity using AntigenPRO and VaxiJen.

\begin{tabular}{|c|c|c|c|c|c|c|c|c|c|c|}
\hline $\begin{array}{c}\text { P. lutzii } \\
\text { Accession }\end{array}$ & $\begin{array}{l}\text { P. brasiliensis } \\
\text { Accession }\end{array}$ & Protein Name & $\begin{array}{c}\text { Localization } \\
\text { WoLF PSORT }\end{array}$ & $\begin{array}{c}\text { Pb01 } \\
\text { AntigenPRO }\end{array}$ & $\begin{array}{c}\text { Pb01 } \\
\text { VaxiJen }\end{array}$ & $\begin{array}{l}\text { Pb01 No. of } \\
\text { Epitopes }\end{array}$ & $\begin{array}{c}\text { Pb18 } \\
\text { AntigenPRO }\end{array}$ & $\begin{array}{c}\text { Pb18 } \\
\text { VaxiJen }\end{array}$ & $\begin{array}{l}\text { Pb18 No. of } \\
\text { Epitopes }\end{array}$ & $\begin{array}{c}\text { Shared } \\
\text { Epitopes }\end{array}$ \\
\hline XP_015702763 & XP_010763025 & NAD(P)H: quinone oxidoreductase, type IV & Extracellular & 0.6407 & 0.4315 & 7 & 0.7233 & 0.5125 & 6 & 0 \\
\hline XP_015700719 & XP_010758121 & $\begin{array}{l}\text { Uncharacterized protein (thioredoxin-like } \\
\text { superfamily) }\end{array}$ & Mitochondrial & 0.9448 & 0.6254 & 12 & 0.9222 & 0.6070 & 10 & 3 \\
\hline XP_002795879 & XP_010762134 & Triosephosphate isomerase & Mitochondrial & 0.6495 & 0.7753 & 11 & 0.7712 & 0.7536 & 13 & 7 \\
\hline XP_002797384 & XP_010759514 & Phenylacetone monooxygenase & Cytoplasmic & 0.8696 & 0.5354 & 17 & 0.8388 & 0.4979 & 16 & 0 \\
\hline XP_015701261 & XP_010756299 & Uncharacterized protein (PRTases type I Superfamily) & Cytoplasmic & 0.8444 & 0.7386 & 5 & 0.7880 & 0.7390 & 5 & 1 \\
\hline XP_002797532 & XP_010762451 & Proteasome subunit alpha & Cytoplasmic & 0.8091 & 0.6841 & 9 & 0.6377 & 0.6426 & 9 & 2 \\
\hline $\mathrm{Q} 8 \mathrm{X} 1 \mathrm{X} 3$ & XP_010758444 & Glyceraldehyde-3-Phosphate dehydrogenase & Cytoplasmic & 0.8114 & 0.7938 & 11 & 0.7921 & 0.8081 & 12 & 5 \\
\hline XP_002796107 & XP_010756450 & Fructose-bisphosphate aldolase 1 & Cytoplasmic & 0.7233 & 0.4472 & 11 & 0.7153 & 0.4869 & 13 & 6 \\
\hline XP_002791734 & XP_010757428 & Mannitol-1-Phosphate 5-dehydrogenase & Cytoplasmic & 0.6436 & 0.5805 & 14 & 0.7117 & 0.5592 & 16 & 2 \\
\hline XP_002790117 & XP_010763478 & HSP72-like protein & Cytoplasmic & 0.8263 & 0.6064 & 20 & 0.8291 & 0.6046 & 23 & 5 \\
\hline XP_002793640 & XP_010760342 & Citrate synthase & Mitochondrial & 0.3002 & 0.4058 & 20 & 0.3103 & 0.4266 & 16 & 7 \\
\hline XP_002791040 & XP_010757468 & Isocitrate lyase & Cytoplasmic & 0.8288 & 0.4291 & 19 & 0.8450 & 0.3904 & 19 & 4 \\
\hline XP_002793534 & XP_010760067 & Transketolase & Cytoplasmic & 0.6889 & 0.7441 & 15 & 0.8113 & 0.6775 & 18 & 6 \\
\hline XP_015703472 & XP_010759701 & Enolase & Cytoplasmic & 0.6237 & 0.8143 & 13 & 0.6419 & 0.7853 & 15 & 4 \\
\hline XP_002789992 & XP_010763632 & HSP60, mitochondrial & Mitochondrial & 0.5421 & 0.9471 & 25 & 0.5124 & 0.9500 & 22 & 6 \\
\hline XP_002797075 & XP_010759641 & Uncharacterized protein & Mitochondrial & 0.8841 & 0.4142 & 10 & 0.8729 & 0.5637 & 8 & 1 \\
\hline XP_002794019 & XP_010762888 & Nucleoside diphosphate kinase & Cytoplasmic & 0.5476 & 0.5195 & 6 & 0.6612 & 0.5236 & 6 & 5 \\
\hline XP_002794671 & XP_010758730 & 1-Cys peroxiredoxin $(\mathrm{PbPrx} 1)$ & Cytoplasmic & 0.8698 & 0.8177 & 9 & 0.8434 & 0.8314 & 10 & 3 \\
\hline XP_002792326 & XP_010763035 & Deoxyuridine $5^{\prime}$-triphosphate nucleotidohydrolase & Mitochondrial & 0.9407 & 0.3919 & 3 & 0.9382 & 0.3264 & 3 & 1 \\
\hline XP_015700963 & XP_010759909 & Proliferating cell nuclear antigen & Nuclear & 0.7182 & 0.6226 & 7 & 0.7234 & 0.7115 & 21 & 1 \\
\hline XP_002791205 & XP_010759842 & Uncharacterized protein (14-3-3 Superfamily) & Cytoplasmic & 0.8629 & 0.5059 & 14 & 0.8728 & 0.5530 & 12 & 6 \\
\hline XP_002796914 & XP_010759301 & 14-3-3 family protein epsilon & Mitochondrial & 0.8586 & 0.5232 & 14 & 0.8844 & 0.5074 & 15 & 8 \\
\hline XP_002793533 & XP_010760066 & Spermidine synthase & Nuclear & 0.3752 & 0.4093 & 11 & 0.4290 & 0.4429 & 8 & 3 \\
\hline XP_002797030 & XP_010759656 & Phosphomannomutase & Cytoplasmic & 0.8278 & 0.6743 & 12 & 0.8003 & 0.6633 & 11 & 0 \\
\hline XP_002789912 & XP_010763814 & 4-hydroxyphenylpyruvate dioxygenase & Cytoplasmic & 0.7016 & 0.5006 & 11 & 0.7664 & 0.4948 & 14 & 4 \\
\hline XP_015701903 & XP_010761900 & Uncharacterized protein (cyclophilin superfamily) & Cytoplasmic & 0.9025 & 0.5236 & 13 & 0.9179 & 0.5328 & 11 & 4 \\
\hline XP_002791109 & XP_010756960 & Thioredoxin reductase & Mitochondrial & 0.8249 & 0.5353 & 12 & 0.8541 & 0.5592 & 12 & 3 \\
\hline XP_002789970 & XP_010763627 & ATP synthase subunit beta & Mitochondrial & 0.4385 & 0.6881 & 25 & 0.2767 & 0.7620 & 21 & 8 \\
\hline XP_002791907 & XP_010763342 & Hexokinase & Cytoplasmic & 0.3520 & 0.8065 & 20 & 0.3815 & 0.8873 & 21 & 6 \\
\hline XP_015700721 & XP_010758595 & HSP75-like protein & Cytoplasmic & 0.8588 & 0.7374 & 21 & 0.8632 & 0.7372 & 22 & 11 \\
\hline XP_002789172 & XP_010761260 & Uncharacterized protein (M20_dimer domain) & Mitochondrial & 0.6981 & 0.7508 & 22 & 0.5960 & 0.6827 & 23 & 11 \\
\hline XP_002797511 & XP_010762465 & $\begin{array}{l}\text { Acetyltransferase component of pyruvate } \\
\text { dehydrogenase complex }\end{array}$ & Mitochondrial & 0.6820 & 0.8293 & 13 & 0.6725 & 0.6868 & 14 & 4 \\
\hline XP_002797127 & XP_010759621 & Protein disulfide-isomerase & Cytoplasmic & 0.8475 & 0.5827 & 19 & 0.8856 & 0.7384 & 19 & 4 \\
\hline XP_015703361 & XP_010756347 & HSP7-like protein & Mitochondrial & 0.7989 & 0.7184 & 27 & 0.9019 & 0.7541 & 27 & 4 \\
\hline XP_002790451 & XP_010758132 & $\begin{array}{l}\text { Uncharacterized protein (NBD sugar kinase } \\
\text { superfamilv) }\end{array}$ & Cytoplasmic & 0.8700 & 0.7442 & 26 & 0.82411 & 0.7502 & 25 & 5 \\
\hline XP_015699682 & XP_010760563 & Aconitate hydratase, mitochondrial & Mitochondrial & 0.7657 & 0.6783 & 27 & 0.766503 & 0.6689 & 23 & 10 \\
\hline
\end{tabular}


For the 16 P. lutzii immunogenic proteins, predicted antigenicity varied from 0.3002 to 0.9448 using AntigenPRO and from 0.4058 to 0.9471 using VaxiJen. Therefore, citrate synthase was not predicted to be an antigen using both predictors. In contrast, VaxiJen failed to predict another four proteins, namely, isocitrate lyase $(0.4291), \mathrm{NAD}(\mathrm{P}) \mathrm{H}$ : quinone oxidoreductase type IV (0.4315), fructose-bisphosphate aldolase 1 (0.4472), and a hypothetical protein (XP_002797075; 0.4142) using a cutoff level of 0.5. Similar predictions were found for the homolog sequences of $P$. brasiliensis (Table 3 ).

Judging from the 25 P. brasiliensis immunogenic proteins, predicted antigenicity varied from 0.2767 to 0.9382 using AntigenPRO and from 0.3264 to 0.95 using VaxiJen. Therefore, ATP synthase subunit beta (0.2767), hexokinase (0.3815), and spermidine synthase (0.429) were not predicted to be antigens using AntigenPRO, and deoxyuridine $5^{\prime}$-triphosphate nucleotidohydrolase (0.3264), spermidine synthase (0.4429), fructose-bisphosphate aldolase 1 (0.4869), and 4-hydroxyphenylpyruvate dioxygenase (0.4948) showed scores below 0.5. Similar predictions were found for the homolog's sequences in P. lutzii (Table 3).

The characterization of epitopes that invoke substantial responses from B-cells is critical in designing useful diagnostic assays, since B-cell epitopes can recognize definite antibodies, thus allowing diagnosis with more specificity. Based on the list of IgG-reactive proteins, epitopes were predicted from the whole protein sequence found in P. lutzii and its homolog in P. brasiliensis (and vice versa). We aimed to describe the candidates for the design of new serological assays and highlight potential vaccine targets for future studies. Our analyses revealed 219 epitopes for P. lutzii and 379 epitopes for P. brasiliensis (Supplementary Table S1). Most of the predicted immunogenic epitopes are accessible on the protein surface, located in flexible regions, and often overlap between P. lutzii and P. brasiliensis, as depicted in Figures 6 and 7, reaching a total of 183 common epitopes. Therefore, although the antigenicity value was found to be somewhat similar between homologs and although the epitope regions were predicted to occur in the same region (Figures 6 and 7), there were substitutions of one or more amino acid residues along with epitopes, which could dramatically decrease the antigen-antibody interaction between the P. lutzii or P. brasiliensis epitopes and the antibodies in heterologous systems. Table 3 shows the number of predicted epitopes and the number of epitopes shared between the antigenic proteins found in 2-D immunoblotting and its homolog in the sister species, indicating they have a chance of cross-reaction with other cryptic Paracoccidioides species causing similar infections. In this scenario, five proteins, namely, 14-3-3 family protein epsilon (Figure 7b), ATP synthase subunit beta, aconitate hydratase, mitochondrial HSP75-like protein, and an uncharacterized protein (M20_dimer domain-containing protein), appeared with the highest number of shared epitopes.

Previous results by our group [22] showed that an immunodominant protein in PCM due to $P$. lutzii occurs in the range of $54 \mathrm{kDa}$, and our 2-D immunoblot revealed a large number of protein spots (Pl20, Pl21, Pl22, Pl23, Pl24, and Pl34) recognized by the P. lutzii antisera. The strongest reactors were observed in the $54 \mathrm{kDa}$ range. The immunodominant protein in the P. lutzii mycosis was identified as enolase (XP_015703472), and characterization of its 3D molecular structure was used to highlight the putative epitopes to improve serodiagnosis of PCM due to P. lutzii (Figure 8a). The homology modeling found for $P$. lutzii enolase used the RaptorX software and revealed that enolase 1 from Saccharomyces cerevisiae (strain ATCC 204508/S288c; PDB ID: 1EBG) [83] was the best template model, showing a sequence identity of $70.81 \%$. PROCHECK analyzed the quality of the model predicted by RaptorX for the evaluation of the Ramachandran plot quality. We found that $90.7 \%$ of the residues of this protein ( 351 amino acid residues) lay in the most favored region, while only three residues were in disallowed regions $(0.8 \%)$, supporting the good quality of the predicted model (Supplementary Figure S2). A comparison between enolase homologs using BepiPred 2.0 revealed 13 epitopes in P. lutzii and 15 epitopes predicted in P. brasiliensis, with only four epitopes shared. We highlight epitope \#2 (pos.40-60: STGQHEACELRDGDQSKWLGK) and epitope \#7 (pos. 195-232: RLRSLSQTEGPRQEEVRQSAGNVGDEGGVAPDIQTPEE) in enolase, which are exclusive to P. lutzii and were shown by ConSurf analysis to be related to exposed residues of the globular protein according to the neural network algorithm (Figure 8b). 
(a)

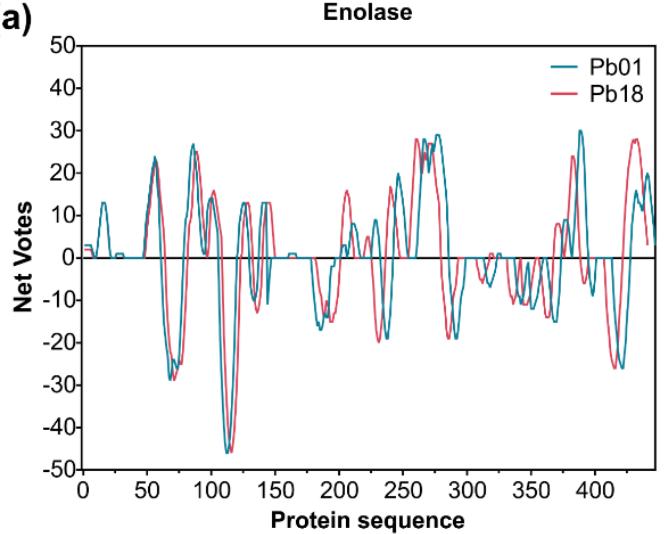

(c)

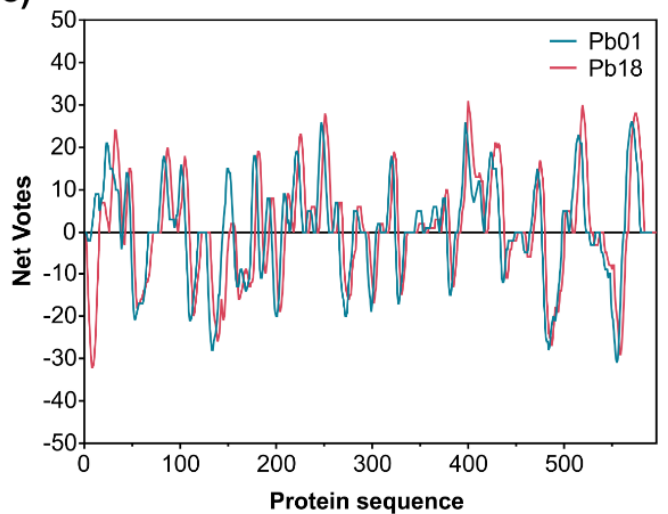

(e) Hypothetical protein (Thioredoxin-like superfamily)

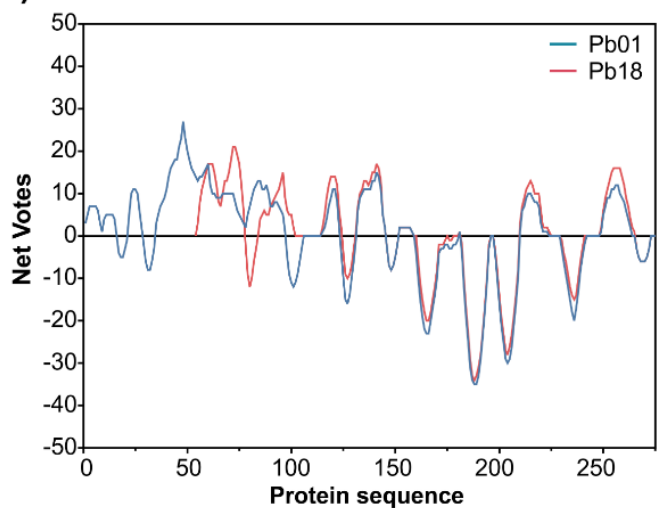

(b)

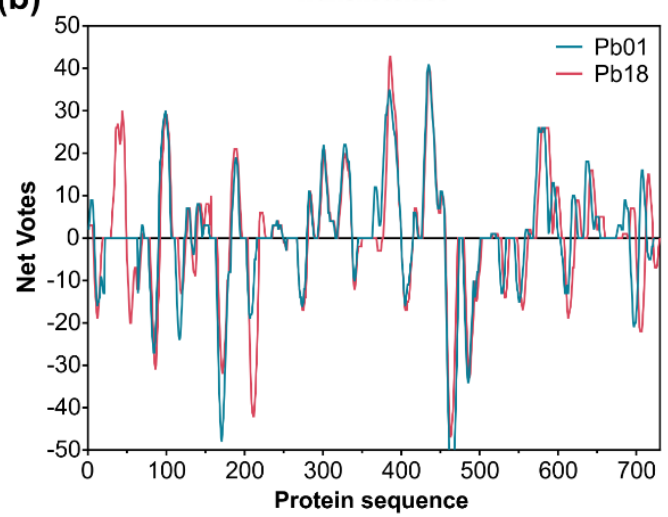

(d)

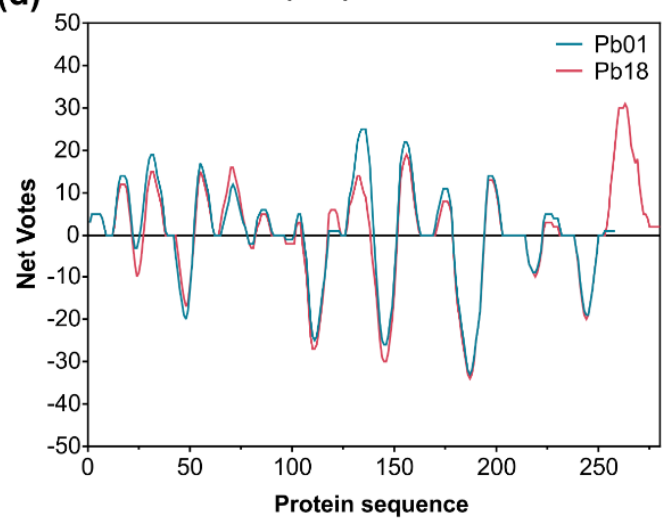

(f) Hypothetical protein (PRTases Type I Superfamily)

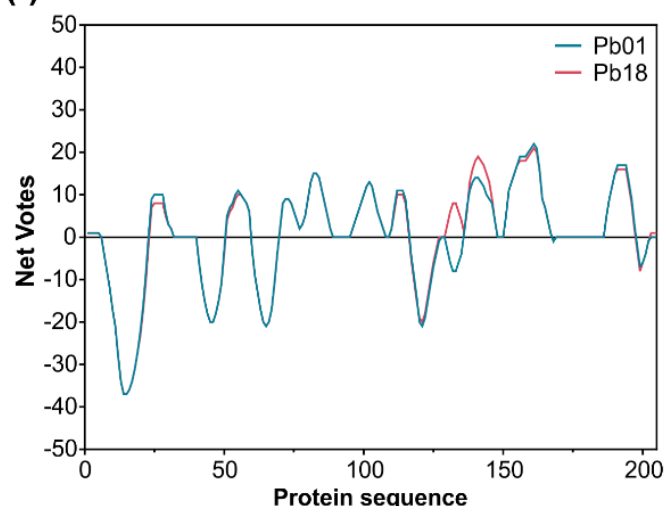

Figure 6. Immunoreactive proteins found in the P. lutzii immunoproteome with the highest antigenic scores. Residue epitope propensity score predictions for (a) enolase (XP_015703472 and XP_010759701), (b) transketolase (XP_002793534 and XP_010760067), (c) heat shock protein 60, mitochondrial (XP_002789992 and XP_010763632), (d) triosephosphate isomerase (XP_002795879 and XP_010762134), (e) uncharacterized protein-Thioredoxin-like superfamily (XP_015700719 and XP_010758121), and (f) uncharacterized protein-PRTases type I superfamily (XP_015701261 and XP_010756299). The antigenic propensity scores are plotted against position along the amino acid sequence as predicted by the COBEpro algorithm [82]. The higher the antigenic propensity scores, the more likely is the antigenic activity for the respective region. COBEpro uses a support vector machine to assign epitope propensity scores to peptide fragments. 
(a)

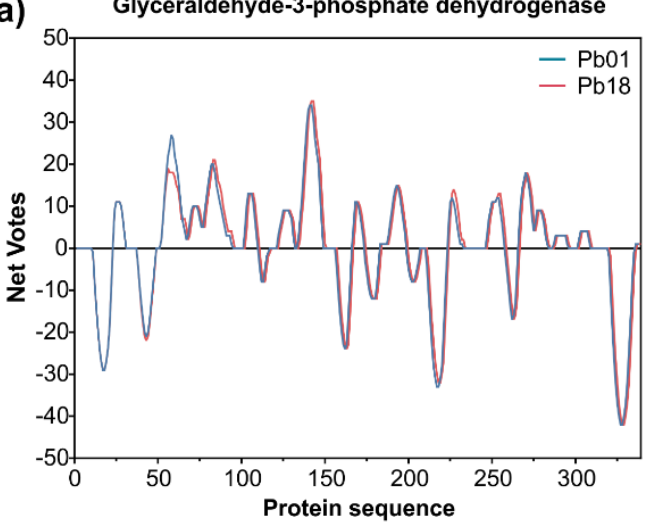

(c)

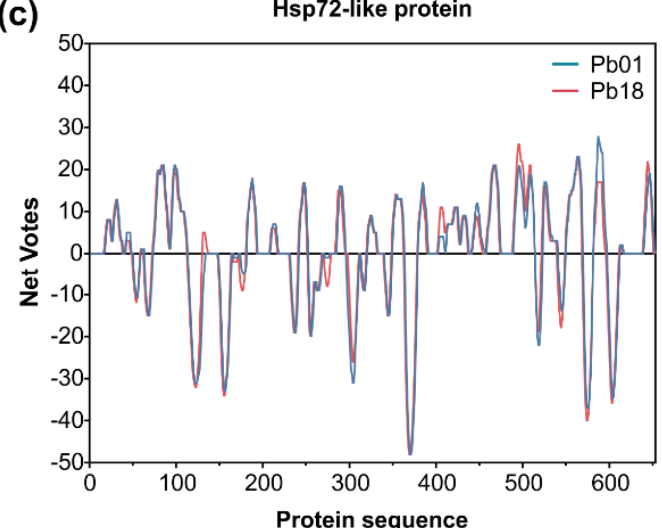

(e)

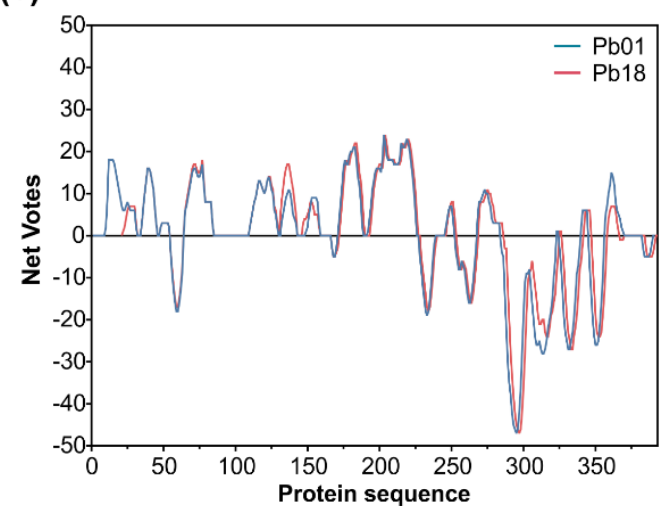

(b)

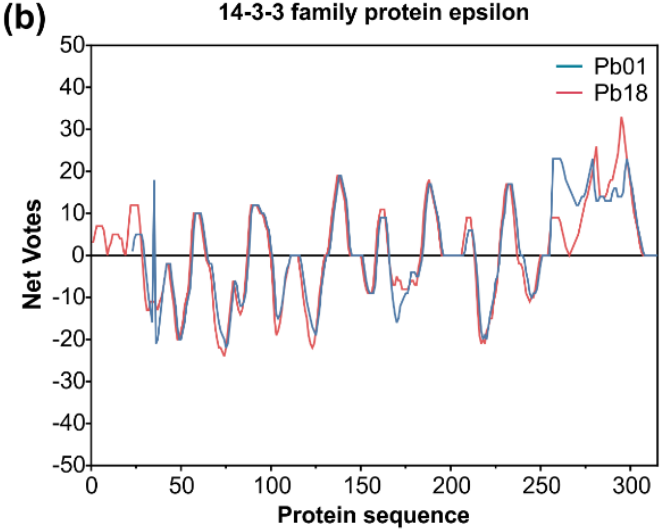

(d)

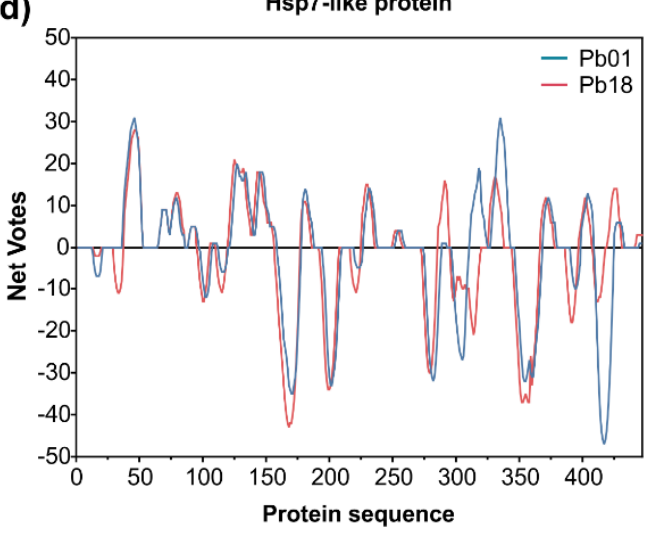

(f)

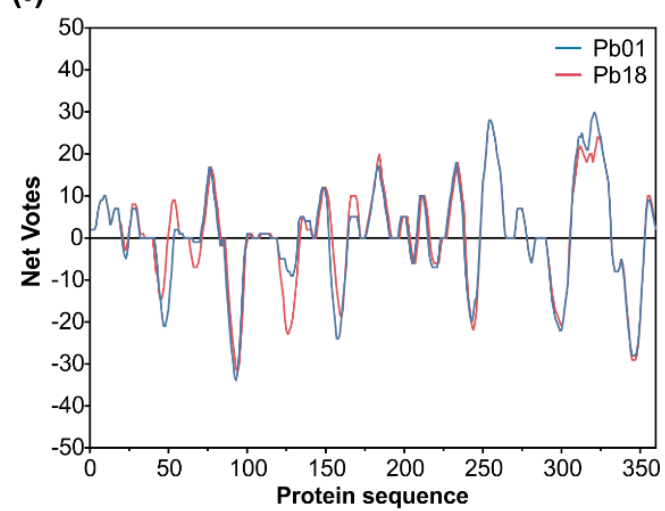

Figure 7. Immunoreactive proteins found in the P. brasiliensis immunoproteome with the highest antigenic scores. Residue epitope propensity score predictions for (a) glyceraldehyde-3-phosphate dehydrogenase (Q8 $\times 1 \times 3$ and XP_010758444), (b) 14-3-3 family protein epsilon (XP_002796914 and XP_010759301), (c) HSP72-like protein (XP_002790117 and XP_010763478), (d) HSP7-like protein (XP_015703361 and XP_010756347), (e) uncharacterized protein—cyclophilin superfamily (XP_015701903 and XP_010761900), and (f) fructose-bisphosphate aldolase 1 (XP_002796107 and $\left.X P \_010756450\right)$. The antigenic propensity scores are plotted against position along the amino acid sequence as predicted by the COBEpro algorithm [82]. The higher the antigenic propensity scores, the more likely is the antigenic activity for the respective region. COBEpro uses a support vector machine to assign epitope propensity scores to peptide fragments. 
(a)
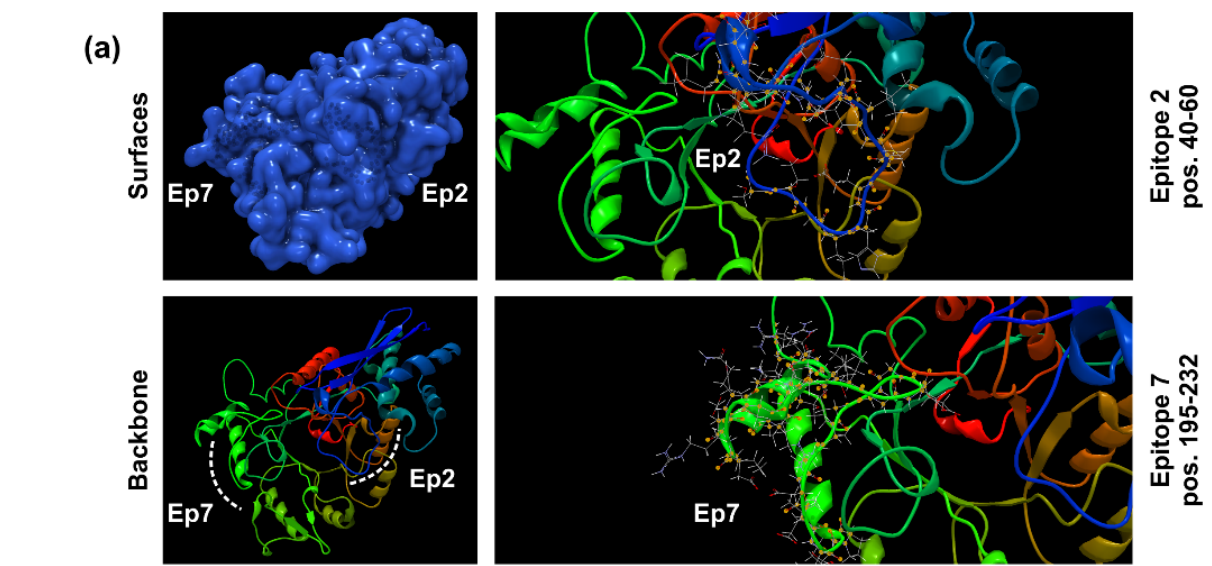

(b)

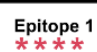

1 MAITK I HARS

f
s

Epitope

51 DGDQSKWL GK

$f$ e e e e e e $f$ Epitope 4
$* * * * * *$

101 P NKSKL GANA

e e e e b e b b b

YDSRGNPTV EVDVVTETGL

bbeeeeeb
fffffff $f$ f

GVLNAVKNVN

f $\mathbf{s} s$

\section{ILGVSLAIAK}

b b b b b b b b be

S s s
Epitope 6

***

151 QNVLNGGSHA

$$
* * *
$$

b b b b b b b e e b

$\mathbf{S}$
Epitope 7
$* * * * * * * * * *$

201 Q T EGPR QEE V

e e e b e b e b b

$* * * * * * * * * *$

RQSAGNVGDE

e e e e e eee

$\mathrm{f} f \mathrm{f} f$
Epitope 9

Epitope 9
$* * * * * * *$

251 K I ALD I ASSE

FYKADEKKYD

b b b b b b b e e b b e e e e e e e
$\mathbf{S} \mathbf{f} f f$

301 A IVS I EDPFA EDDWEAWSYY

e b b b e e e b e

e e e e b beb

351 NA L L LKVNQ I

eb b b b e b e e

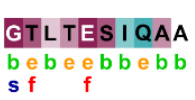

401 LR A G I K T GA

beeeebeee

s f $f$

\section{PARSERLAKL}

e e e bee e e b

SV IGPA I I KE

e e b b e e bee

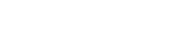

AGAAEKGVPL

bebee e b e b

s s

I VPTYGPL LG

b b b b e b e b e

s

$* * * * * * * * * *$

GGVAPD I QT P

e e e e e bee

$* * * * * * * * *$ LDFKNPD K

be e e e e e e

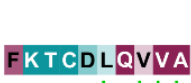

e e e e e b b b b
$f$ ss

KDSYAAGWGV

ebbee e b e b

NQ I LR I EEEL

e e b b e b e e b

s $s f$
* - Bepipred linear epitope prediction 2.0 - Exposed residu - Buried residue
Epitope 2

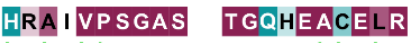

bebebbeee eeeeebbebe

S 5 f $f f f$

Epitope 3

NIDVKDQSKV DEFLNKLDGT

e e e e e eeb e e b b beb e e e
$f f f f$

Epitope 5

*** ***

YAHVSDLAGT KKPYVLPVPF

bebbeeeee ee eeebebbb

f
Epitope 7
$* * * * * *$

IALRCPVLLR GPPPRLRSLS

e b b e ebbebb be e e b e ebb

**

EEALDL I TEA

s

beeeeceeb

$* * * * * * * * * \quad * *$

SKWLTYEQLA DLYKKLASKY

e e e e eeebb ebbeebbeeb

Epitope 11

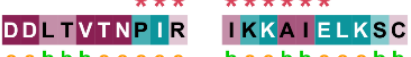

e ebbbeee e e beebbeeebb

$f \quad s f f$

\section{Epitope 12}

MVSHRSGETE DVTIADIVVG

b b beeeee e b e b e e b b b b

Epitope 13
$* * * * * *$

b e e b e e

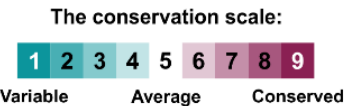

f - Predicted functional residue (highly conserved and exposed).
s - A predicted structural residue (highly conserved and buried).

- Insufficient data - the calculation for this site was

performed on less than $10 \%$ of the sequences.

Figure 8. B-cell epitopes are exposed in the P. lutzii enolase. A comparative model for enolase was obtained from the Protein Data Bank (PDB; http://www.rcsb.org/pdb/) webserver [84], and the Saccharomyces cerevisiae enolase 1 (strain ATCC 204508/S288c; PDB ID: 1EBG) [83], showing a sequence identity of $70.81 \%$, was selected as a template model. (a) Protein surface view (blue) based on prediction $\left(p=5.1 \times 10^{-12}\right)$ using RaptorX [80]. Epitope $2($ Ep2) and epitope 7 (Ep7) are exclusive of P. lutzii and are indicated in the zoom area. A yellow dot indicates amino acid residues in the epitopes. (b) ConSurf analysis of the enolase protein structure of P. lutzii (accession number: XP_015703472) reveals that the 13 predicted B-cell epitopes (red asterisks) match exposed residues. Amino acid residues are color coded by their conservation grades using a nine-grade color-coding bar (bin 1 to 9), with turquoise-through-maroon indicating variable through conserved. The conservation calculation was performed on a sample of 150 sequences representing the list of homologs to the query XP_015703472. The figure also reveals the functionally and structurally important regions of the enolase. 


\section{Discussion}

The recent introduction of dissimilar species in Paracoccidioides has raised important questions about the immunodiagnosis of this disease. We highlight the paradoxical diagnosis in PCM, where the same patient may present positive mycological exams, with the observation of pathognomonic structures related to Paracoccidioides species, whereas serological tests, such as immunodiffusion, show no reactivity in the presence of the reference antigen AgPbB339 [15]. The phylogenetic recognition of P. lutzii brought the first clue to solving this problem [35,47], and currently regional antigenic preparations are recommended for use in areas of occurrence of this fungus, such as the Brazilian Midwest $[12,13,22,85,86]$. The second clue to solving this puzzle emerges from this study, where we performed immunoproteomic analysis of the Paracoccidioides yeast cells aiming to screen potential biomarkers for the refinement of the immunodiagnosis of PCM due to P. lutzii.

The 16 specific immunogenic proteins of $P$. lutzii can be divided into three main groups. Group 1 comprises seven proteins that have been widely reported in Paracoccidioides under experimental physiological conditions according to STRING analysis, namely, triosephosphate isomerase, glyceraldehyde-3-phosphate dehydrogenase, citrate synthase, isocitrate lyase, enolase, HSP60-like protein, and an uncharacterized protein (thioredoxin-like superfamily) [54,70,87-93]. Proteins included in group 2 are antigens that already have been described in human PCM, such as triosephosphate isomerase, glyceraldehyde-3-phosphate dehydrogenase, fructose-bisphosphate aldolase [70], or Paracoccidioides antigens that already have been related to eliciting a humoral immune response in BALB/c mice, such as transketolase, HSP60-like protein, and isocitrate lyase (all shared with PS3) [71]. Finally, proteins in the last group correspond to novel immunogens, described for the first time in P. lutzii mycosis, such as $\mathrm{NAD}(\mathrm{P}) \mathrm{H}$ : quinone oxidoreductase, type IV, phenylacetone monooxygenase, proteasome subunit alpha, mannitol-1-phosphate 5-dehydrogenase, HSP72-like protein, and two uncharacterized proteins (XP_015701261 and XP_002797075).

Paracoccidioides brasiliensis s. str. was used as a comparative group, and to our surprise only five proteins were found to be shared between P. lutzii and P. brasiliensis (triosephosphate isomerase, glyceraldehyde-3-phosphate dehydrogenase, fructose-bisphosphate aldolase 1, and HSP72-like protein, and HSP60, mitochondrial). The immunoproteome of human PCM due to P. brasiliensis s. str. shares only two proteins with those described as eliciting a humoral immune response in $\mathrm{BALB} / \mathrm{c}$ mice, including HSP7-like protein (shared with PS2) and HSP 60-like protein (shared with P. lutzii, S1, PS2, and PS3) [71]. This suggests that more research on this neglected system will reveal a greater number of antigens shared between closely related cryptic species. The 25 specific immunogenic proteins of $P$. brasiliensis can be divided into three main groups. Group 1 comprises 13 proteins that have already been described in Paracoccidioides under experimental physiological condition, namely, triosephosphate isomerase, spermidine synthase, glyceraldehyde-3-phosphate dehydrogenase, 4-hydroxyphenylpyruvate dioxygenase, thioredoxin reductase, ATP synthase subunit beta, hexokinase, HSP75-like protein, HSP60-like protein, HSP7-like protein, aconitate hydratase, mitochondrial, 1-Cys peroxiredoxin, and an uncharacterized protein (XP_010758132) [54,70,87-95], all of them enriched in our STRING network. Proteins in group 2 correspond to antigens that have already been described in human PCM [70] or immunogens that have already been described to elicit a humoral immune response in BALB/c mice, such as HSP7-like protein and HSP 60-like protein [71]. Proteins in group 3 correspond to novel antigens, such as nucleoside diphosphate kinase, deoxyuridine 5 '-triphosphate nucleotidohydrolase, proliferating cell nuclear antigen, 14-3-3 family protein epsilon, phosphomannomutase, HSP72-like protein, the acetyltransferase component of pyruvate dehydrogenase complex, disulfide-isomerase, and four uncharacterized proteins (XP_010759842, XP_010761900, XP_010761260, and XP_010758132) described for the first time in P. brasiliensis mycosis.

Among the proteins identified by us, most are involved in metabolic pathways (KEGG map01100), carbon metabolism (KEGG map01200), and biosynthesis of secondary metabolites (KEGG map01110) in both immunoproteomes (Supplementary Figure S3). Recently, Amaral et al. [54] reported that 
genes involved in gluconeogenesis are upregulated in highly virulent Paracoccidioides species, as the protein levels related to carbohydrate metabolism increase. Remarkable progress has been achieved to reveal the potential carbon sources during infection using A. fumigatus, C. albicans, and C. neoformans exposed to immune cells or in infection models [96-99]. Parallels between the response of these fungi to phagocytosis include enhancement of metabolic pathways required during carbon starvation, along with gluconeogenesis, fatty acid metabolism, and the glyoxylate shunt, many of which are targets of the carbon catabolite repression system in these fungi [100]. The increased expression levels of gluconeogenesis-related proteins during Paracoccidioides infection may expose these proteins to the host immune system. In this respect, proteins involved in the metabolic and carbon metabolism pathways were found to be recognized by circulating IgG antibodies in sera of patients that developed PCM due to P. lutzii and P. brasiliensis s. str.

Fungi evolved in a polyphyletic manner, developing different lifestyles, ranging from saprophytic to human pathogenic [101]. Consequently, their metabolic flexibility has been influenced by numerous evolutionary pressures [102,103]. Fungal metabolic pathways allow them to grow in diverse host niches and synthesize an array of potent small molecules [102,103]. Therefore, metabolism is essential to the Paracoccidioides pathogenicity, and there is significant importance of nitrogen [104], carbon [105], and micronutrient assimilation [91], allowing them to express key virulence factors [54].

The response of Paracoccidioides to macrophage infection shows that the fungus most likely faces a nutrient-limited environment in macrophage phagosomes, because a significantly higher expression of genes encoding isocitrate lyase was detected in earlier studies $[92,105,106]$. In Candida albicans, isocitrate lyase is a critical enzyme for virulence in the glyoxylate cycle, and its increased activity has been shown to be an important marker for gluconeogenic carbon source utilization and starvation $[97,107]$. Indeed, isocitrate lyase has been shown to elicit a humoral response in BALB/C mice challenged with exoantigens from members of the P. brasiliensis complex [71], and here, we found that isocitrate lyase is an antigen in PCM due to P. lutzii.

Interestingly, glyceraldehyde-3-phosphate dehydrogenase and fructose-bisphosphate aldolase are expressed in high levels among highly virulent $P$. brasiliensis complex isolates found to trigger disseminated disease in a murine model of PCM $[54,106]$ and have been observed in Paracoccidioides extracellular vesicle preparations of the $\mathrm{Pb} 18$ isolate [90]. Therefore, the vesicular transport may deliver substances across the Paracoccidioides cell wall, possibly modulating the host's immune response and supporting the high virulence of phenotypes [54,108]. Both proteins elicited humoral responses in human PCM due to P. lutzii and P. brasiliensis s. str.

Proteins employed in carbon metabolism and metabolic or MAPK signaling pathways and that have been found in the Paracoccidioides cell walls are implicated in adhesion to matrix-associated components. We found that glyceraldehyde-3-phosphate dehydrogenase, enolase, triosephosphate isomerase, 14-3-3 protein, and fructose-1,6-bisphosphate aldolase [109-116] elicited IgG antibodies during PCM. Paracoccidioides moonlighting proteins have different functions inside and outside the cell. Many enzymes have multiple functions when secreted or when attached to the cell surface. Usually, the mechanisms behind the moonlighting proteins' delivery and how some become attached to the cell surface are enigmatic [117]. Nevertheless, Vallejo et al. [90] proposed that extracellular vesicles act as an efficient and general mechanism of secretion of pathogenesis-related molecules in Paracoccidioides, delivering a concentrated payload of fungal products to host effector cells and tissues [118]. Here, we demonstrated that moonlighting proteins in Paracoccidioides elicited a humoral response in human PCM, so it is tempting to hypothesize that extracellular vesicles function as "virulence bags" [118], dispensing antigens during human PCM (Figure 9). The presence of these moonlighting proteins in vesicles produced by other fungi has already been demonstrated for Histoplasma capsulatum [119], Cryptococcus neoformans [118], and Saccharomyces cerevisiae [120]. These moonlighting proteins are usually present in increased levels in the fungus cell wall during interaction with host cells, suggesting they may be involved in host-parasite interactions and virulence $[95,116,121-123]$. Some of these proteins have already been demonstrated to be crucial 
vaccine candidates in pathogenic fungi (e.g., glyceraldehyde-3-phosphate dehydrogenase, enolase, 14-3-3 protein, and fructose-1,6-bisphosphate aldolase), since they are highly expressed and have low identity with homolog proteins in the human host [124,125].

\section{Antigenic panel of Paracoccidioides species}

\section{P. brasiliensis}

\section{Cytoplasmic}

- Nucleoside diphosphate kinase $\bigcirc$

- Uncharacterized protein

(14-3-3 Superfamily)

Phosphomannomutase

4-hydroxyphenylpyruvate

dioxygenase

Uncharacterized protein

(Cyclophilin superfamily)

- Hexokinase $O$

-HSP75-like protein

- Protein disulfide-isomerase 0000

- Uncharacterized protein

(NBD sugar kinase HSP70

actin superfamily)

1-Cys peroxiredoxin $\bigcirc$

(PbPrx1)

Nuclear
-Proliferating cell
nuclear antigen
-Spermidine synthase

\section{Shared antigens:}

- Glyceraldehyde-3-Phosphate 00000 dehydrogenase

-Fructose-bisphosphate

aldolase 1

-HSP72-like protein

\section{P. Iutzii}

\section{Cytoplasmic}

-Phenylacetone monooxygenase - Uncharacterized protein (PRTases type I Superfamily) -Proteasome subunit alpha 0 -Mannitol-1-Phosphate 00 5-dehydrogenase - Isocitrate lyase 000 - Transketolase 000 - Enolase 00

\section{Extracellular}

- $\mathrm{NAD}(\mathrm{P}) \mathrm{H}$ : quinone oxidoreductase, type IV

\section{Mitochondria}

-Deoxyuridine 5'-triphosphate $\bigcirc \bigcirc$ nucleotidohydrolase

-14-3-3 family protein epsilon $\bigcirc$

- Thioredoxin reductase $\mathrm{OO}$

-ATP synthase subunit beta

- Uncharacterized protein

(M20 dimer domain)

Acetyltransferase component of

pyruvate dehydrogenase complex

-HSP7-like protein 0

-Aconitate hydratase

mitochondrial
Antigens already described in:

Human PCM

Murine model

Proteins shown to be related to:
Virulence
Interacting with macrophages

\section{Mitochondria}

- Uncharacterized protein (XP_002797075)

- Uncharacterized protein

(Thioredoxin-like)

- Citrate synthase $\bigcirc$

Figure 9. A panel of immunogenic proteins in paracoccidioidomycosis caused by P. brasiliensis sensu stricto (left) and P. lutzii (right). The immunogenic proteins were grouped according to the subcellular localization predicted by the WoLF PSORT [69]. Pieces of information about the report of these proteins as antigens in human [70] or murine PCM [71], the presence in the cell wall $[95,116,126]$ and extracellular vesicles [90], during interaction with macrophages [122] or associated with virulence processes in Paracoccidioides $[54,57,106]$ were noted. The illustration was partially based on Servier Medical Art elements and licensed under a Creative Commons Attribution 3.0 Unported License. ER: endoplasmic reticulum.

Interestingly, the $43 \mathrm{kDa}$ glycoprotein (gp43), a classic antigen of P. brasiliensis [127], also implicated in adhesion to matrix associated components [128], was not found in our immunoproteomes. However, 
a 1-D immunoblot using the purified gp43 protein [129] revealed that anti-gp43 antibodies were present in the serum pool of patients infected with P. brasiliensis s. str. (Supplementary Figure S4). Therefore, the lack of reaction in the 2-D immunoblot may be because the strain $\mathrm{Pb} 18$ (S1) used in our experiments is a weaker producer of gp43 compared to the isolate B-339 (PS3) [130,131], combined with technical limitations related to 2-D electrophoresis, where proteins can be lost during the purification and transfer process, making detection unfeasible [132]. Although common epitopes between P. lutzii and P. brasiliensis gp43 exist, anti-gp43 MAbs (MAb3e, Mab17c, Mab19g, MAb21f, or MAb32) do not recognize the recombining orthologous $P$. lutzii protein [133] nor did antibodies from patients infected with P. lutzii recognize the native B-339 [22], supporting the idea that B-339 gp43 cannot be used in the diagnosis of PCM caused by P. lutzii [133].

The serology of PCM due to P. lutzii draws attention to the intense reaction of a fraction oscillating in the range of $54 \mathrm{kDa}$ in immunoblots [22,85], which has been proposed as the immunodominant antigen in P. lutzii mycosis [22]. However, the protein sequence of this immunogenic fraction had not been identified until the present study. In our experiments, we also observed an intense reaction in the range of $54 \mathrm{kDa}$, and interestingly, several spots were identified as enolase. The surface-associated enolase is upregulated in Paracoccidioides yeast cells derived from mouse-infected tissues [112], and in agreement with our results, it has been described as an isoform with increased abundance in the P. lutzii proteome [93]. This protein binds to plasminogen and mediates the interaction of yeast forms with host cells [134], suggesting that enolase may contribute to the pathogenesis of Paracoccidioides (Figure 9).

Moreover, it is well known that this adhesin can be inhibited by a specific antibody, influencing the fungus' adhesion to pulmonary cells. Therefore, the presence of IgG antibodies against $P$. lutzii enolase in the serum of patients supports the importance of these molecules during the host-pathogen interplay $[111,135]$, and it is tempting to hypothesize that post-translational modification of enolase is responsible for regulation of the immune response during P. lutzii infection. A monoclonal antibody raised against the enolase cell-surface protein of Aspergillus fumigatus exhibited diagnostic and therapeutic potential, inhibiting spore germination and presenting a fungicidal activity against a broad range of Aspergillus infections [136]. Future studies with the recombinant enolase protein or enolase B-cell epitopes may elucidate the specificity and sensitivity of antienolase antibodies' detection and refine the immunodiagnosis of $P$. lutzii mycosis.

Energy production pathways in yeast cells of $P$. lutzii are driven by glycolysis and fermentation, whereas $P$. brasiliensis yeast cells preferentially use aerobic betaoxidation and the citrate cycle (TCA cycle) for ATP production [91]. Proteins related to the oxidative phosphorylation and TCA cycle include citrate synthase, aconitate hydratase, ATP synthase subunit beta, and acetyltransferase component of pyruvate dehydrogenase complex, which were found to be immunogenic during PCM. Citrate synthase catalyzes the entry of carbon into the citric acid cycle, and in Paracoccidioides, methylcitrate synthase transcripts and proteins and aconitate hydratase are upregulated throughout the adaptation to environmental conditions during the increase in the temperature [91]. Experimental data shows that P. lutzii presents an elevated methylcitrate synthase activity even when glucose is the sole carbon source, and two-dimensional Western blot data revealed a different pattern in isoform distribution with low mass variation, suggesting the presence of varying phosphorylation patterns [137]. Here, a single spot citrate synthase was recognized by antibodies circulating in sera of patients with PCM due to P. lutzii. ATP synthase subunit beta is one of the P. lutzii-secreted proteins that interacts with macrophages [122], and here, it was recognized by IgG in the sera of P. brasiliensis mycosis patients. F-ATP synthases are molecular rotary motors that catalyze ATP synthesis from ADP and inorganic phosphate using the proton-motive force generated by substrate-driven electron transfer chains [138]. Acetyltransferase component of pyruvate dehydrogenase complex, a gene involved in the TCA cycle, was found to be IgG-reactive in PCM due to P. brasiliensis although experimental data shows that it is downregulated upon $6 \mathrm{~h}$ postinfection of mouse lung compared with the in vitro control [106] (Figure 9).

Proteins related to DNA replication and mismatch repairs such as the proliferating cell nuclear antigen (PCNA) and deoxyuridine $5^{\prime}$-triphosphate nucleotidohydrolase (dUTPase) were found to be 
immunogenic in the system P. brasiliensis-PCM. dUTPase (EC 3.6.1.23) catalyzes the conversion of dUTP to dUMP and pyrophosphate (PPi), providing the substrate for methylation of uracil by thymidylate synthase and preventing accidental incorporation of uracil into DNA by DNA-polymerase $[139,140]$. Interestingly, dUTPase has been described in the secretome of P. lutzii, and experimental data show that this protein interacts with macrophage proteins [122]. Notwithstanding, PCNA is described for the first time as an antigen in PCM. PCNA synthesis correlates with the proliferative state of the cell that has been found in the nuclei of yeasts, plants, and animal cells that undergo cell division, suggesting a function in cell cycle regulation and DNA replication [141,142]. Afterward, PCNA was shown to also play an essential role in other processes involving the cell genome [141,142], and in Paracoccidioides, it has been observed in the cell wall [116].

A total of seven antigenic proteins detected in our analysis matched uncharacterized protein. This finding was not surprising as Desjardins et al. [143] reported that approximately $60 \%$ of Paracoccidioides genes were encoding hypothetical proteins with undetermined cellular functions with no evidence of in vivo expression [144]. Such finding is common in Paracoccidioides species [93] as it has poor databases and a lack of proteomic studies compared to model organisms. To the extent of our knowledge, this is the first report describing the hypothetical proteins XP_015701261 (PRTases type I superfamily) and XP_002797075 as antigens in P. lutzii immunoproteome. Both proteins were predicted to be antigens by AntigenPRO with high scores. Interestingly, the uncharacterized protein XP_002797075 was predicted to be in the mitochondria of Paracoccidioides. As antibodies were from infected patients, this strongly suggests that these proteins are expressed in vivo during PCM.

A hypothetical protein (XP_015700719) containing domains with a thioredoxin-like fold was immunogenic in P. lutzii proteome. Recent studies investigating the humoral response in BALB/c mice revealed antibodies targeting an uncharacterized protein with a thioredoxin-like superfamily domain in PS3 secretome [71], similar to the response found in our study in human PCM. Likewise, other four uncharacterized protein was found to be immunogenic exclusively in the P. brasiliensis immunoproteome, including a hypothetical protein containing a 14-3-3 superfamily domain (XP_010759842), a cyclophilin superfamily domain (XP_010761900), an M20_dimer domain-containing protein (XP_010761260), and an NBD sugar kinase superfamily (XP_010758132). Indeed, in silico characterization of P. brasiliensis hypothetical proteins sequences using AntigenPRO and VaxiJen predicted them to be antigens with scores above 0.5 . Further studies will be needed to characterize all these hypothetical proteins and understand its role in PCM infection.

During infection, nutrient starvation results in common stress for fungal pathogens, leading to primary and secondary metabolism changes. Secondary metabolites are crucial players in fungal development and actively shape interactions with other organisms [145]. A cluster of proteins related to the biosynthesis of amino acids and purine metabolism was immunogenic in PCM, including nucleoside diphosphate kinase, spermidine synthase, 4-hydroxyphenylpyruvate dioxygenase, which are found in the Paracoccidioides species' cell wall [116] (Figure 9). Spermidine synthase and 4-hydroxyphenylpyruvate dioxygenase are among the most abundant upregulated proteins of $P$. lutzii yeast cells under carbon starvation [105]. In contrast, nucleoside diphosphate kinase was described as an adhesin-like molecule, identified during copper-deprivation conditions in P. lutzii in the presence of extracellular matrix components [146].

Four molecular chaperones named "HSP60, HSP72, HSP75, and HSP7" were identified as antigens in P. lutzii or P. brasiliensis proteomes. Molecular chaperones, usually known as heat shock proteins, are a diverse family of proteins that are upregulated under conditions of stress and operate to protect proteins from irreversible aggregation during synthesis and in times of cellular stress [147,148]. These molecular chaperones have been demonstrated to be modulated during the nitrosative stress in P. brasiliensis, suggesting that they play essential roles in fungal virulence [149]. Remarkably, the HSP60 protein, have been primarily explored in fungal cells and recognized to be crucial for cell growth [150], survival in the host, morphogenesis [151,152], germination, and conidiation [153]. Immune responses 
to the three molecular chaperones (HSP60, HSP70, and HSP7) elicit the production of both specific antibodies in BALB/c mice challenged with proteins secreted by Paracoccidioides species [71].

The thioredoxin system, a central antioxidant system in nearly all living cells, comprises thioredoxin, thioredoxin reductase, and NADPH [154]. A cluster of proteins involved in the pentose phosphate pathway, including thioredoxin reductase, hexokinase, mannitol-1-phosphate 5-dehydrogenase, $\mathrm{NAD}(\mathrm{P}) \mathrm{H}$ : quinone oxidoreductase, type $\mathrm{IV}$, and phenylacetone monooxygenase, were recognized by antibodies circulating in the sera of patients with PCM. Proteomic analyses demonstrated that thioredoxin reductase was induced in Paracoccidioides during murine infection [106], and along with hexokinase, they were detected among the group of upregulated proteins upon carbon starvation in Paracoccidioides [105]. Hexokinase is present in the secretome and in the cell wall of Paracoccidioides species [116,155]. Mannitol-1-phosphate 5-dehydrogenase was described as a virulence factor in Paracoccidioides, and we found that this protein elicits IgG antibodies during P. lutzii infection. In pathogenic fungi, the improved stress resistance resulting from accumulated six-carbon polyol D-mannitol enhances the ability to deal with defense strategies of the infected host [156]. Mannitol is known to quench reactive oxygen species (ROS) [157], and there is some evidence that fungi use mannitol to suppress ROS-mediated host defenses $[156,158]$. NAD(P)H: quinone oxidoreductase, type IV and phenylacetone monooxygenase, two enzymes that belong to the family of oxidoreductases and catalyze the transfer of electrons from oxidant to reductant [159-161], were identified as antigens in the proteome of P. lutzii. Indeed, cytosolic quinone reductase is a critical component of pathogenicity during the host-fungus interaction [162,163].

A unique P. brasiliensis 1-Cys peroxiredoxin (PbPrx1; XP_010758730) was only recently reported to localize in the cytoplasm and at the cell wall of the yeast and mycelial forms of P. brasiliensis, as well as in the yeast mitochondria [95]. Longo et al. suggest a possible role of PbPrx1 in the fungal antioxidant defense mechanisms [95], and here, we report PbPrx1 as an antigen in human PCM due to P. brasiliensis s. str. Interestingly, in plants, 1-Cys peroxiredoxin has been shown to not only relieve oxidative stresses but also play a central role as molecular chaperones under severe conditions during seed germination, and that overoxidation controls the switch in function of 1-Cys-peroxiredoxins from peroxidases to molecular chaperones [164]. In fungal pathogens, analyses of the three 1-Cys peroxiredoxins from A. fumigatus reveal that they act together to maintain the redox balance, playing a significant role in pathogenicity [165], two aspects that could be regulated by antibodies during Paracoccidioides infection.

Phosphomannomutase was found to be immunogenic in the system P. brasiliensis-PCM. This enzyme catalyzes the interconversion of mannose-6-phosphate and mannose-1-phosphate, and in Saccharomyces cerevisiae, phosphomannomutase (Sec53p) is essential for viability [155]. However, a proteomic study found that phosphomannomutase is preferentially secreted in P. lutzii compared to P. restrepiensis [155]. A sequence related to protein degradation, such as the proteasome subunit alpha, was identified as antigenic in P. lutzii mycosis. Proteasome is a highly sophisticated protease complex that promotes selective and efficient processive hydrolysis of intracellular client proteins in eukaryotic cells, a process that requires metabolic energy [166].

In the second part of our study, we analyzed the prediction of linear epitopes for B-cells. It is important to mention that epitope-based antibodies are currently the most promising classes of biopharmaceutical protein products [167]. Significant advances in immunoinformatics tools have revolutionized the development of diagnostic assays and vaccine design [168]. The latest tools available for analyzing antigenic properties and epitopes associated with the pathogen include AntigenPRO, BCPred, SVMTriP, COBEpro, and IEDB tools like BepiPred, Ellipro, etc. [169-171]. The identification of Paracoccidioides antigens was followed by in silico analysis to predict B-cell epitope, producing a library of 219 and 379 epitopes predicted for P. lutzii and P. brasiliensis, respectively. These are all good candidates for serological diagnosis of PCM. Interestingly, two synthetic peptides, named "P2 and L15," have been proposed for the serodiagnosis of PCM [172,173], and our panel of epitopes can significantly increase in the number of peptides used in immunodiagnosis of PCM in the coming years. 
The lack of good-quality diagnostic tests for Paracoccidioides infection causes slow diagnosis, and consequently poor prognosis of this neglected mycosis in the Americas. Since PCM's clinical manifestations lack specificity, confirmatory tests are required to identify humans infected with Paracoccidioides spp. Further studies are under way to map these epitopes in vitro. Several antibody-detection assays employing crude preparations or recombinant proteins have been developed for laboratory diagnosis of PCM [17-19,21,24-26,48,174-179]. However, a diagnostic method with high specificity and sensitivity to guide the management and control remains to be developed for P. lutzii. We believe that a new generation of diagnostic tests with the expected high sensitivity and specificity should be composed of various linear B-cell epitopes, mapped in silico from the Paracoccidioides antigens identified in this study. The current clinical data on PCM have shown great overlap of clinical signs due to distinct Paracoccidioides species $[12,14,180]$. Therefore, the best strategy for the immunodiagnosis still involves differentiation between P. lutzii and members of the P. brasiliensis complex instead of stressing a multimarker diagnostic assay, which will likely pose a major challenge regarding specificity and sensitivity for successful implementation. A sensitive and affordable point-of-care assay is mandatory for an important neglected mycosis such as PCM, which is usually associated with poverty.

\section{Conclusions}

Our study was carried out using proteomic and in silico analysis, and we were able to identify novel antigens that represent a panel of key targets for humoral response against $P$. lutzii and P. brasiliensis s. str., the most common agents of PCM in a vast area of the Americas. This is the first study to report specific antigens in the yeast phase of cryptic Paracoccidioides species using a gold-standard human serum. We identified the major antigen of PCM due to P. lutzii as enolase, and several B-cell epitopes were predicted in the Paracoccidioides-PCM system. Hypothetical proteins were found to elicit an antibody response in human PCM, so were identified as antigens. Further studies employing some of these native and recombinant proteins will be conducted to develop an accurate diagnostic test and an effective vaccine, identify infected hosts, and prevent infection and development of human PCM. The findings reported here provide a unique opportunity for the refinement of diagnostic tools of this important neglected systemic mycosis.

Supplementary Materials: The following are available online at http://www.mdpi.com/2309-608X/6/4/357/s1, Figure S1: Anti-Paracoccidioides antibody titers in reactive sera of patients with paracoccidioidomycosis due to $P$. brasiliensis sensu stricto $(\mathrm{S} 1 ; n=10)$ or $P$. lutzii $(n=10)$. NHS: normal human serum (sera from the healthy normal donors; $n=10$ ). A quantitative double immunodiffusion assay (DID) was used to establish the titration of each patient's serum using (a) the exoantigens from the reference B-339 strain (AgPbB339; PS3) or (b) a P. lutzii CFA preparation derived from the reference isolate EPM208 as described earlier [21,22]. Each dot represents the result of a single patient. Bars represent the lowest (Min) and the highest (Max) value in each column. Figure S2: Ramachandran plot generated by PROCHECK validation server [81] showing the stereochemical quality of the Paracoccidioides lutzii enolase structure (accession number: XP_015703472). Figure S3: Overview of the metabolic pathways in (a) P. lutzii and (b) P. brasiliensis proteomes. The red lines represent proteins (IgG immunoreactive) that were highly enriched, and the boxes represent metabolic pathways. These metabolic maps were visualized and analyzed by the web application iPath3.0 [68]. Figure S4: Representative immunoblot of purified gp43 antigen (B-339 strain) using sera from patients with confirmed paracoccidioidomycosis due to P. brasiliensis s. str. ( $\mathrm{Pb}$, yellow lane) or P. lutzii ( $\mathrm{Pl}$, green lane). Table S1: BepiPred Linear Epitope Prediction 2.0 results.

Author Contributions: Conceptualization, Z.P.d.C. and A.M.R.; methodology, A.M.R., P.H.K.-B., B.G.P., R.C.H., and A.T.-F.; software, A.M.R., P.H.K.-B., and A.T.-F.; validation, A.M.R. and Z.P.d.C.; formal analysis, A.M.R., P.H.K.-B., A.T.-F., and Z.P.d.C.; investigation, A.M.R.; resources, A.M.R., P.H.K.-B., A.T.-F., R.C.H., and Z.P.d.C.; data curation, A.M.R. and Z.P.d.C.; writing - original draft preparation, A.M.R.; writing — review and editing, A.M.R. and Z.P.d.C.; visualization, A.M.R. and Z.P.d.C.; supervision, A.M.R. and Z.P.d.C.; project administration, A.M.R. and Z.P.d.C.; funding acquisition, A.M.R. and Z.P.d.C. All authors have read and agreed to the published version of the manuscript.

Funding: This study was funded by the Fundação de Amparo à Pesquisa do Estado de São Paulo (2017/27265-5 and 2018/21460-3) http://www.fapesp.br/, Conselho Nacional de Desenvolvimento Científico e Tecnológico (CNPq 429594/2018-6) http://www.cnpq.br/, and Coordenação de Aperfeiçoamento de Pessoal de Nível Superior (CAPES 88887.177846/2018-00) https://www.capes.gov.br/. 
Acknowledgments: We thank the staff of the Toxinology and Pathology Laboratories-IOC/Fiocruz for their assistance with the mass spectrometric analysis (Proteomic Network, Rio de Janeiro, RJ, Brazil).

Conflicts of Interest: The authors declare no conflict of interest. The funders had no role in the design of the study; the collection, analyses or interpretation of data; the writing of the manuscript; or the decision to publish the results.

\section{References}

1. Lutz, A. Uma micose pseudococídica localizada na boca e observada no Brasil: Contribuição ao conhecimento das hifoblastomicoses americanas. Bras. Med. 1908, 22, 121-124.

2. De Almeida, F. Estudos comparativos do granuloma coccidióidico nos Estados Unidos e no Brasil. Novo gênero para o parasito brasileiro. An. Fac. Med. Sao Paulo 1930, 5, 125-141.

3. Brummer, E.; Castaneda, E.; Restrepo, A. Paracoccidioidomycosis: An update. Clin. Microbiol. Rev. 1993, 6, 89-117. [CrossRef] [PubMed]

4. Restrepo, A.; McEwen, J.G.; Castaneda, E. The habitat of Paracoccidioides brasiliensis: How far from solving the riddle? Med. Mycol. 2001, 39, 233-241. [CrossRef]

5. Bocca, A.L.; Amaral, A.C.; Teixeira, M.M.; Sato, P.K.; Shikanai-Yasuda, M.A.; Soares Felipe, M.S. Paracoccidioidomycosis: Eco-epidemiology, taxonomy and clinical and therapeutic issues. Future Microbiol. 2013, 8, 1177-1191. [CrossRef]

6. Queiroz-Telles, F.; Fahal, A.H.; Falci, D.R.; Caceres, D.H.; Chiller, T.; Pasqualotto, A.C. Neglected endemic mycoses. Lancet Infect. Dis. 2017, 17, e367-e377. [CrossRef]

7. Colombo, A.L.; Tobon, A.; Restrepo, A.; Queiroz-Telles, F.; Nucci, M. Epidemiology of endemic systemic fungal infections in Latin America. Med. Mycol. 2011, 49, 785-798. [CrossRef]

8. De Deus Vieira, G.; da Cunha Alves, T.; de Lima, S.M.D.; Camargo, L.M.A.; de Sousa, C.M. Paracoccidioidomycosis in a western Brazilian Amazon State: Clinical-epidemiologic profile and spatial distribution of the disease. Rev. Soc. Bras. Med. Trop. 2014, 47, 63-68. [CrossRef]

9. Paniago, A.M.M.; Aguiar, J.I.A.; Aguiar, E.S.; da Cunha, R.V.; de Pereira, G.R.O.L.; Londero, A.T.; Wanke, B. Paracoccidioidomycosis: A clinical and epidemiological study of 422 cases observed in Mato Grosso do Sul. Rev. Soc. Bras. Med. Trop. 2003, 36, 455-459. [CrossRef]

10. Coutinho, Z.F.; Silva, D.; Lazera, M.; Petri, V.; Oliveira, R.M.; Sabroza, P.C.; Wanke, B. Paracoccidioidomycosis mortality in Brazil (1980-1995). Cad. Saude Publica 2002, 18, 1441-1454. [CrossRef]

11. San-Blas, F.; Cova, L.J. Growth curves of the yeast-like form of Paracoccidioides brasiliensis. Sabouraudia 1975, 13, 22-29. [CrossRef] [PubMed]

12. Hahn, R.C.; Rodrigues, A.M.; Della Terra, P.P.; Nery, A.F.; Hoffmann-Santos, H.D.; Góis, H.M.; Fontes, C.J.; de Camargo, Z.P. Clinical and epidemiological features of paracoccidioidomycosis due to Paracoccidioides lutzii. PLoS Negl. Trop. Dis. 2019, 13, e0007437. [CrossRef] [PubMed]

13. Hahn, R.C.; Rodrigues, A.M.; Fontes, C.J.; Nery, A.F.; Tadano, T.; de Padua Queiroz Junior, L.; de Camargo, Z.P. Fatal Fungemia due to Paracoccidioides lutzii. Am. J. Trop. Med. Hyg. 2014, 91, 394-398. [CrossRef] [PubMed]

14. Pereira, E.F.; Gegembauer, G.; Chang, M.R.; Camargo, Z.P.D.; Nunes, T.F.; Ribeiro, S.M.; Carvalho, L.R.D.; Maldonado, B.M.; Mendes, R.P.; Paniago, A.M.M. Comparison of clinico-epidemiological and radiological features in paracoccidioidomycosis patients regarding serological classification using antigens from Paracoccidioides brasiliensis complex and Paracoccidioides lutzii. PLoS Negl. Trop. Dis. 2020, 14, e0008485. [CrossRef] [PubMed]

15. Camargo, Z.P.; Rodrigues, A.M. Paracoccidioides Complex. In Pocket Guide to Mycological Diagnosis; Cordeiro, R.A., Ed.; CRC Press: Boca Raton, FL, USA, 2019; Volume 78, pp. 125-134.

16. Pinheiro, B.G.; Hahn, R.C.; Camargo, Z.P.; Rodrigues, A.M. Molecular tools for detection and identification of Paracoccidioides species: Current status and future perspectives. J. Fungi 2020, 6, 293. [CrossRef] [PubMed]

17. Marques da Silva, S.H.; Queiroz-Telles, F.; Colombo, A.L.; Blotta, M.H.S.L.; Lopes, J.D.; de Camargo, Z.P. Monitoring gp43 antigenemia in paracoccidioidomycosis patients during therapy. J. Clin. Microbiol. 2004, 42, 2419-2424. [CrossRef] [PubMed]

18. Marques da Silva, S.H.; de Mattos Grosso, D.; Lopes, J.D.; Colombo, A.L.; Blotta, M.H.S.L.; Queiroz-Telles, F.; de Camargo, Z.P. Detection of Paracoccidioides brasiliensis gp70 circulating antigen and follow-up of patients undergoing antimycotic therapy. J. Clin. Microbiol. 2004, 42, 4480-4486. [CrossRef] 
19. Marques-da-Silva, S.H.; Colombo, A.L.; Blotta, M.H.S.L.; Lopes, J.D.; Queiroz-Telles, F.; de Camargo, Z.P. Detection of circulating gp43 antigen in serum, cerebrospinal fluid, and bronchoalveolar lavage fluid of patients with paracoccidioidomycosis. J. Clin. Microbiol. 2003, 41, 3675-3680. [CrossRef]

20. Martins, R.; Marques, S.; Alves, M.; Fecchio, D.; de Franco, M.F. Serological follow-up of patients with paracoccidioidomycosis treated with itraconazole using Dot-blot, ELISA and western-blot. Rev. Inst. Med. Trop. Sao Paulo 1997, 39, 261-269. [CrossRef]

21. de Camargo, Z.P.; Unterkircher, C.; Campoy, S.P.; Travassos, L.R. Production of Paracoccidioides brasiliensis exoantigens for immunodiffusion tests. J. Clin. Microbiol. 1988, 26, 2147-2151. [CrossRef]

22. Gegembauer, G.; Araujo, L.M.; Pereira, E.F.; Rodrigues, A.M.; Paniago, A.M.; Hahn, R.C.; de Camargo, Z.P. Serology of paracoccidioidomycosis due to Paracoccidioides lutzii. PLoS Negl. Trop. Dis. 2014, 8, e2986. [CrossRef] [PubMed]

23. Bellissimo-Rodrigues, F.; Vitali, L.H.; Martinez, R. Serological diagnosis of paracoccidioidomycosis in HIV-coinfected patients. Mem. Inst. Oswaldo Cruz 2010, 105, 904-907. [CrossRef] [PubMed]

24. De Camargo, Z.P.; Guesdon, J.L.; Drouhet, E.; Improvisi, L. Enzyme-linked immunosorbent assay (ELISA) in the paracoccidioidomycosis. Comparison with counterimmunoelectrophoresis and erythro-immunoassay. Mycopathologia 1984, 88, 31-37. [CrossRef] [PubMed]

25. Dos Santos, P.O.; Rodrigues, A.M.; Fernandes, G.F.; da Silva, S.H.; Burger, E.; de Camargo, Z.P. Immunodiagnosis of paracoccidioidomycosis due to Paracoccidioides brasiliensis using a latex test: Detection of specific antibody anti-gp43 and specific antigen gp43. PLoS Negl. Trop. Dis. 2015, 9, e0003516. [CrossRef] [PubMed]

26. Camargo, Z.P.; Unterkircher, C.; Travassos, L.R. Identification of antigenic polypeptides of Paracoccidioides brasiliensis by immunoblotting. Med. Mycol. 1989, 27, 407-412. [CrossRef]

27. Camargo, Z.P. Serology of paracoccidioidomycosis. Mycopathologia 2008, 165, 289-302. [CrossRef]

28. Matute, D.R.; McEwen, J.G.; Puccia, R.; Montes, B.A.; San-Blas, G.; Bagagli, E.; Rauscher, J.T.; Restrepo, A.; Morais, F.; Niño-Vega, G.; et al. Cryptic speciation and recombination in the fungus Paracoccidioides brasiliensis as revealed by gene genealogies. Mol. Biol. Evol. 2006, 23, 65-73. [CrossRef]

29. Matute, D.R.; Sepulveda, V.E.; Quesada, L.M.; Goldman, G.H.; Taylor, J.W.; Restrepo, A.; McEwen, J.G. Microsatellite analysis of three phylogenetic species of Paracoccidioides brasiliensis. J. Clin. Microbiol. 2006, 44, 2153-2157. [CrossRef]

30. Morais, F.V.; Barros, T.F.; Fukada, M.K.; Cisalpino, P.S.; Puccia, R. Polymorphism in the gene coding for the immunodominant antigen gp43 from the pathogenic fungus Paracoccidioides brasiliensis. J. Clin. Microbiol. 2000, 38, 3960. [CrossRef]

31. Hebeler-Barbosa, F.; Morais, F.V.; Montenegro, M.R.; Kuramae, E.E.; Montes, B.; McEwen, J.G.; Bagagli, E.; Puccia, R. Comparison of the sequences of the internal transcribed spacer regions and PbGP43 genes of Paracoccidioides brasiliensis from patients and armadillos (Dasypus novemcinctus). J. Clin. Microbiol. 2003, 41, 5735. [CrossRef]

32. Del Negro, G.; Garcia, N.; Rodrigues, E.; Assis, C.; Melo, N.; Lacaz, C.D.S. Note on Paracoccidioides tenuis Moore 1938 a possible synonym for Paracoccidioides brasiliensis. Rev. Iberoam. Micol. 1993, 10, 69-71.

33. Moore, M. A new species of the Paracoccidioides Almeida (1930): P. cerebriformis Moore, (1935). Rev. Biol. Hig. $1935,6,148-162$.

34. Gezuele, E. Aislamiento de Paracoccidioides sp. de heces de pinguino de la Antartida. In Proceedings of the IV International Symposium on Paracoccidioidomycosis, Caracas, Venezuela, 10-14 April 1989; pp. 10-14.

35. Teixeira, M.M.; Theodoro, R.C.; de Carvalho, M.J.A.; Fernandes, L.; Paes, H.C.; Hahn, R.C.; Mendoza, L.; Bagagli, E.; San-Blas, G.; Felipe, M.S.S. Phylogenetic analysis reveals a high level of speciation in the Paracoccidioides genus. Mol. Phylogenet. Evol. 2009, 52, 273-283. [CrossRef] [PubMed]

36. Theodoro, R.C.; Teixeira, M.d.M.; Felipe, M.S.S.; Paduan, K.D.S.; Ribolla, P.M.; San-Blas, G.; Bagagli, E. Genus Paracoccidioides: Species recognition and biogeographic aspects. PLoS ONE 2012, 7, e37694. [CrossRef]

37. Teixeira, M.M.; Theodoro, R.C.; Nino-Vega, G.; Bagagli, E.; Felipe, M.S.S. Paracoccidioides species complex: Ecology, phylogeny, sexual reproduction, and virulence. PLoS Pathog. 2014, 10, e1004397. [CrossRef]

38. Vandamme, P.; Pot, B.; Gillis, M.; de Vos, P.; Kersters, K.; Swings, J. Polyphasic taxonomy, a consensus approach to bacterial systematics. Microbiol. Rev. 1996, 60, 407-438. [CrossRef]

39. Jančič, S.; Nguyen, H.D.T.; Frisvad, J.C.; Zalar, P.; Schroers, H.-J.; Seifert, K.A.; Gunde-Cimerman, N. A taxonomic revision of the Wallemia sebi species complex. PLoS ONE 2015, 10, e0125933. [CrossRef] 
40. Quaedvlieg, W.; Binder, M.; Groenewald, J.Z.; Summerell, B.A.; Carnegie, A.J.; Burgess, T.I.; Crous, P.W. Introducing the consolidated species concept to resolve species in the Teratosphaeriaceae. Persoonia 2014, 33, 1-40. [CrossRef]

41. Muñoz, J.F.; Farrer, R.A.; Desjardins, C.A.; Gallo, J.E.; Sykes, S.; Sakthikumar, S.; Misas, E.; Whiston, E.A.; Bagagli, E.; Soares, C.M.A.; et al. Genome diversity, recombination, and virulence across the major lineages of Paracoccidioides. mSphere 2016, 1, e00213-16.

42. De Melo Teixeira, M.; Cattana, M.E.; Matute, D.R.; Muñoz, J.F.; Arechavala, A.; Isbell, K.; Schipper, R.; Santiso, G.; Tracogna, F.; de los Ángeles Sosa, M.; et al. Genomic diversity of the human pathogen Paracoccidioides across the South American continent. Fungal Genet. Biol. 2020, 140, 103395. [CrossRef]

43. Cocio, T.A.; Nascimento, E.; Kress, M.R.; Bagagli, E.; Martinez, R. Characterization of a Paracoccidioides spp. strain from southeastern Brazil genotyped as Paracoccidioides restrepiensis (PS3) and review of this phylogenetic species. Genet. Mol. Biol. 2020, 43, e20190201. [CrossRef] [PubMed]

44. Cocio, T.A.; Nascimento, E.; von Zeska Kress, M.R.; Bagagli, E.; Martinez, R. Phylogenetic species of Paracoccidioides spp. isolated from clinical and environmental samples in a hyperendemic area of paracoccidioidomycosis in Southeastern Brazil. J. Fungi 2020, 6, 132. [CrossRef] [PubMed]

45. Marques-da-Silva, S.H.; Rodrigues, A.M.; de Hoog, G.S.; Silveira-Gomes, F.; de Camargo, Z.P. Occurrence of Paracoccidioides lutzii in the Amazon region: Description of two cases. Am. J. Trop. Med. Hyg. 2012, 87, 710-714. [CrossRef] [PubMed]

46. Sarmento Tatagiba, L.; Bridi Pivatto, L.; Faccini-Martínez, Á.A.; Mendes Peçanha, P.; Grão Velloso, T.R.; Gonçalves, S.S.; Messias Rodrigues, A.; Pires Camargo, Z.; Falqueto, A. A case of paracoccidioidomycosis due to Paracoccidioides lutzii presenting sarcoid-like form. Med. Mycol. Case Rep. 2018, 19, 6-8. [CrossRef]

47. Teixeira, M.M.; Theodoro, R.C.; Oliveira, F.F.; Machado, G.C.; Hahn, R.C.; Bagagli, E.; San-Blas, G.; Felipe, M.S. Paracoccidioides lutzii sp. nov.: Biological and clinical implications. Med. Mycol. 2014, 52, 19-28. [CrossRef]

48. Blotta, M.H.; Camargo, Z.P. Immunological response to cell-free antigens of Paracoccidioides brasiliensis: Relationship with clinical forms of paracoccidioidomycosis. J. Clin. Microbiol. 1993, 31, 671-676. [CrossRef]

49. Ohyama, K.; Kuroda, N. Immune Complexome Analysis. In Advances in Clinical Chemistry; Makowski, G.S., Ed.; Elsevier: Amsterdam, The Netherlands, 2013; Volume 60, pp. 129-141.

50. Ballesté, R.N. Proteomics: Technology and Applications. In The Use of Mass Spectrometry Technology (MALDI-TOF) in Clinical Microbiology; Cobo, F., Ed.; Academic Press: Cambridge, MA, USA, 2018; pp. 1-17. [CrossRef]

51. Haas, G.; Karaali, G.; Ebermayer, K.; Metzger, W.G.; Lamer, S.; Zimny-Arndt, U.; Diescher, S.; Goebel, U.B.; Vogt, K.; Roznowski, A.B.; et al. Immunoproteomics of Helicobacter pylori infection and relation to gastric disease. Proteomics 2002, 2, 313-324. [CrossRef]

52. Gautam, P.; Sundaram, C.S.; Madan, T.; Gade, W.N.; Shah, A.; Sirdeshmukh, R.; Sarma, P.U. Identification of novel allergens of Aspergillus fumigatus using immunoproteomics approach. Clin. Exp. Allergy 2007, 37, 1239-1249. [CrossRef]

53. Costa, M.M.; Andrade, H.M.; Bartholomeu, D.C.; Freitas, L.M.; Pires, S.F.; Chapeaurouge, A.D.; Perales, J.; Ferreira, A.T.; Giusta, M.S.; Melo, M.N.; et al. Analysis of Leishmania chagasi by 2-D difference gel eleTrop.horesis (2-D DIGE) and immunoproteomic: Identification of novel candidate antigens for diagnostic tests and vaccine. J. Proteome Res. 2011, 10, 2172-2184. [CrossRef]

54. Do Amaral, C.C.; Fernandes, G.F.; Rodrigues, A.M.; Burger, E.; de Camargo, Z.P. Proteomic analysis of Paracoccidioides brasiliensis complex isolates: Correlation of the levels of differentially expressed proteins with in vivo virulence. PLoS ONE 2019, 14, e0218013. [CrossRef]

55. Roberto, T.N.; Rodrigues, A.M.; Hahn, R.C.; de Camargo, Z.P. Identifying Paracoccidioides phylogenetic species by PCR-RFLP of the alpha-tubulin gene. Med. Mycol. 2016, 54, 240-247. [CrossRef] [PubMed]

56. Brummer, E.; Restrepo, A.; Hanson, L.H.; Stevens, D.A. Virulence of Paracoccidiodes brasiliensis: The influence of in vitro passage and storage. Mycopathologia 1990, 109, 13-17. [CrossRef] [PubMed]

57. Castilho, D.G.; Chaves, A.F.; Xander, P.; Zelanis, A.; Kitano, E.S.; Serrano, S.M.; Tashima, A.K.; Batista, W.L. Exploring potential virulence regulators in Paracoccidioides brasiliensis isolates of varying virulence through quantitative proteomics. J. Proteome Res. 2014, 13, 4259-4271. [CrossRef] [PubMed]

58. Rodrigues, A.M.; Kubitschek-Barreira, P.H.; Fernandes, G.F.; de Almeida, S.R.; Lopes-Bezerra, L.M.; de Camargo, Z.P. Immunoproteomic analysis reveals a convergent humoral response signature in the Sporothrix schenckii complex. J. Proteom. 2015, 115, 8-22. [CrossRef] [PubMed] 
59. Missall, T.A.; Pusateri, M.E.; Donlin, M.J.; Chambers, K.T.; Corbett, J.A.; Lodge, J.K. Posttranslational, translational, and transcriptional responses to nitric oxide stress in Cryptococcus neoformans: Implications for virulence. Eukaryot. Cell 2006, 5, 518-529. [CrossRef]

60. Bradford, M.M. A rapid and sensitive method for the quantitation of microgram quantities of protein utilizing the principle of protein-dye binding. Anal. Biochem. 1976, 72, 248-254. [CrossRef]

61. Blum, H.; Beier, H.; Gross, H.J. Improved silver staining of plant proteins, RNA and DNA in polyacrylamide gels. Electrophoresis 1987, 8, 93-99. [CrossRef]

62. Candiano, G.; Bruschi, M.; Musante, L.; Santucci, L.; Ghiggeri, G.M.; Carnemolla, B.; Orecchia, P.; Zardi, L.; Righetti, P.G. Blue silver: A very sensitive colloidal Coomassie G-250 staining for proteome analysis. Electrophoresis 2004, 25, 1327-1333. [CrossRef]

63. Towbin, H.; Staehelin, T.; Gordon, J. ElecTrop.horetic transfer of proteins from polyacrylamide gels to nitrocellulose sheets: Procedure and some applications. Proc. Natl. Acad. Sci. USA 1979, 76, 4350-4354. [CrossRef]

64. Della Terra, P.P.; Rodrigues, A.M.; Fernandes, G.F.; Nishikaku, A.S.; Burger, E.; de Camargo, Z.P. Exploring virulence and immunogenicity in the emerging pathogen Sporothrix brasiliensis. PLoS Negl. Trop. Dis. 2017, 11, e0005903. [CrossRef]

65. Munoz, J.F.; Gallo, J.E.; Misas, E.; Priest, M.; Imamovic, A.; Young, S.; Zeng, Q.; Clay, O.K.; McEwen, J.G.; Cuomo, C.A. Genome update of the dimorphic human pathogenic fungi causing paracoccidioidomycosis. PLoS Negl. Trop. Dis. 2014, 8, e3348. [CrossRef] [PubMed]

66. Szklarczyk, D.; Gable, A.L.; Lyon, D.; Junge, A.; Wyder, S.; Huerta-Cepas, J.; Simonovic, M.; Doncheva, N.T.; Morris, J.H.; Bork, P.; et al. STRING v11: Protein-protein association networks with increased coverage, supporting functional discovery in genome-wide experimental datasets. Nucleic Acids Res. 2019, 47, D607-D613. [CrossRef] [PubMed]

67. Kanehisa, M.; Goto, S.; Kawashima, S.; Okuno, Y.; Hattori, M. The KEGG resource for deciphering the genome. Nucleic Acids Res. 2004, 32, D277-D280. [CrossRef] [PubMed]

68. Darzi, Y.; Letunic, I.; Bork, P.; Yamada, T. iPath3.0: Interactive pathways explorer v3. Nucleic Acids Res. 2018, 46, W510-W513. [CrossRef]

69. Horton, P.; Park, K.-J.; Obayashi, T.; Fujita, N.; Harada, H.; Adams-Collier, C.J.; Nakai, K. WoLF PSORT: Protein localization predictor. Nucleic Acids Res. 2007, 35, W585-W587. [CrossRef]

70. Da Fonseca, C.A.; Jesuino, R.S.A.; Felipe, M.S.S.; Cunha, D.A.; Brito, W.A.; Soares, C.M.A. Two-dimensional elecTrop.horesis and characterization of antigens from Paracoccidioides brasiliensis. Microbes Infect. 2001, 3, 535-542. [CrossRef]

71. Moreira, A.L.E.; Oliveira, M.A.P.; Silva, L.O.H.S.; Inácio, M.M.; Bailão, A.M.; Parente-Rocha, J.A.; Cruz-Leite, V.R.M.; Paccez, J.D.; de Almeida Soares, C.M.; Weber, S.S.; et al. Immunoproteomic approach of extracellular antigens from Paracoccidioides species reveals exclusive B-Cell epitopes. Front. Microbiol. 2020, 10, 2968. [CrossRef]

72. Saha, S.; Raghava, G.P. Prediction of continuous B-cell epitopes in an antigen using recurrent neural network. Proteins 2006, 65, 40-48. [CrossRef]

73. Jespersen, M.C.; Peters, B.; Nielsen, M.; Marcatili, P. BepiPred-2.0: Improving sequence-based B-cell epitope prediction using conformational epitopes. Nucleic Acids Res. 2017, 45, W24-W29. [CrossRef]

74. Magnan, C.N.; Zeller, M.; Kayala, M.A.; Vigil, A.; Randall, A.; Felgner, P.L.; Baldi, P. High-throughput prediction of protein antigenicity using protein microarray data. Bioinformatics 2010, 26, 2936-2943. [CrossRef]

75. Doytchinova, I.A.; Flower, D.R. VaxiJen: A server for prediction of protective antigens, tumour antigens and subunit vaccines. BMC Bioinform. 2007, 8, 4. [CrossRef] [PubMed]

76. Ashkenazy, H.; Abadi, S.; Martz, E.; Chay, O.; Mayrose, I.; Pupko, T.; Ben-Tal, N. ConSurf 2016: An improved methodology to estimate and visualize evolutionary conservation in macromolecules. Nucleic Acids Res. 2016, 44, W344-W350. [CrossRef] [PubMed]

77. Katoh, K.; Standley, D.M. MAFFT multiple sequence alignment software version 7: Improvements in performance and usability. Mol. Biol. Evol. 2013, 30, 772-780. [CrossRef] [PubMed]

78. Suzek, B.E.; Wang, Y.; Huang, H.; McGarvey, P.B.; Wu, C.H.; the UniProt, C. UniRef clusters: A comprehensive and scalable alternative for improving sequence similarity searches. Bioinformatics 2015, 31, 926-932. [CrossRef] 
79. Finn, R.D.; Clements, J.; Eddy, S.R. HMMER web server: Interactive sequence similarity searching. Nucleic Acids Res. 2011, 39, W29-W37. [CrossRef]

80. Källberg, M.; Wang, H.; Wang, S.; Peng, J.; Wang, Z.; Lu, H.; Xu, J. Template-based protein structure modeling using the RaptorX web server. Nat. Protoc. 2012, 7, 1511-1522. [CrossRef]

81. Laskowski, R.A.; MacArthur, M.W.; Moss, D.S.; Thornton, J.M. PROCHECK: A program to check the stereochemical quality of protein structures. J. Appl. Crystallogr. 1993, 26, 283-291. [CrossRef]

82. Sweredoski, M.J.; Baldi, P. COBEpro: A novel system for predicting continuous B-cell epitopes. Protein Eng. Des. Sel. 2009, 22, 113-120. [CrossRef]

83. Wedekind, J.E.; Poyner, R.R.; Reed, G.H.; Rayment, I. Chelation of Serine 39 to $\mathrm{Mg}^{2+}$ latches a gate at the active site of enolase: Structure of the $\operatorname{Bis}\left(\mathrm{Mg}^{2+}\right)$ Complex of yeast enolase and the intermediate analog phosphonoacetohydroxamate at 2.1-.ANG. resolution. Biochemistry 1994, 33, 9333-9342. [CrossRef]

84. Berman, H.M.; Westbrook, J.; Feng, Z.; Gilliland, G.; Bhat, T.N.; Weissig, H.; Shindyalov, I.N.; Bourne, P.E. The Protein Data Bank. Nucleic Acids Res. 2000, 28, 235-242. [CrossRef]

85. Queiroz Junior Lde, P.; de Camargo, Z.P.; Tadano, T.; Rodrigues, A.M.; Takarara, D.T.; Gegembauer, G.; Araujo, L.M.; Hahn, R.C. Serological and antigenic profiles of clinical isolates of Paracoccidioides spp. from Central Western Brazil. Mycoses 2014, 57, 466-472. [CrossRef] [PubMed]

86. Batista, J., Jr.; de Camargo, Z.P.; Fernandes, G.F.; Vicentini, A.P.; Fontes, C.J.F.; Hahn, R.C. Is the geographical origin of a Paracoccidioides brasiliensis isolate important for antigen production for regional diagnosis of paracoccidioidomycosis? Mycoses 2010, 53, 176-180. [CrossRef] [PubMed]

87. Assato, P.A.; da Silva Jde, F.; de Oliveira, H.C.; Marcos, C.M.; Rossi, D.; Valentini, S.R.; Mendes-Giannini, M.J.; Zanelli, C.F.; Fusco-Almeida, A.M. Functional analysis of Paracoccidioides brasiliensis 14-3-3 adhesin expressed in Saccharomyces cerevisiae. BMC Microbiol. 2015, 15, 256. [CrossRef] [PubMed]

88. Longo, L.V.; Nakayasu, E.S.; Pires, J.H.; Gazos-Lopes, F.; Vallejo, M.C.; Sobreira, T.J.; Almeida, I.C.; Puccia, R. Characterization of lipids and proteins associated to the cell wall of the acapsular mutant Cryptococcus neoformans cap 67. J. Eukaryot. Microbiol. 2015, 62, 591-604. [CrossRef] [PubMed]

89. Silva, L.D.C.; Tauhata, S.B.F.; Baeza, L.C.; de Oliveira, C.M.A.; Kato, L.; Borges, C.L.; de Almeida Soares, C.M.; Pereira, M. Argentilactone molecular targets in Paracoccidioides brasiliensis identified by chemoproteomics. Antimicrob. Agents Chemother. 2018, 62. [CrossRef] [PubMed]

90. Vallejo, M.C.; Nakayasu, E.S.; Matsuo, A.L.; Sobreira, T.J.; Longo, L.V.; Ganiko, L.; Almeida, I.C.; Puccia, R. Vesicle and vesicle-free extracellular proteome of Paracoccidioides brasiliensis: Comparative analysis with other pathogenic fungi. J. Proteome Res. 2012, 11, 1676-1685. [CrossRef] [PubMed]

91. Araújo, D.S.; Pereira, M.; Portis, I.G.; Dos Santos Junior, A.C.M.; Fontes, W.; de Sousa, M.V.; Assunção, L.D.P.; Baeza, L.C.; Bailão, A.M.; Ricart, C.A.O.; et al. Metabolic peculiarities of Paracoccidioides brasiliensis dimorphism as demonstrated by iTRAQ labeling proteomics. Front. Microbiol. 2019, 10, 555. [CrossRef]

92. Baeza, L.C.; da Mata, F.R.; Pigosso, L.L.; Pereira, M.; de Souza, G.; Coelho, A.S.G.; de Almeida Soares, C.M. Differential metabolism of a two-carbon substrate by members of the Paracoccidioides genus. Front. Microbiol. 2017, 8, 2308. [CrossRef]

93. Pigosso, L.L.; Parente, A.F.; Coelho, A.S.; Silva, L.P.; Borges, C.L.; Bailao, A.M.; Soares, C.M. Comparative proteomics in the genus Paracoccidioides. Fungal Genet. Biol. 2013, 60, 87-100. [CrossRef]

94. Wang, L.; Wu, X.; Gao, W.; Zhao, M.; Zhang, J.; Huang, C. Differential expression patterns of Pleurotus ostreatus catalase genes during developmental stages and under heat stress. Genes 2017, 8, 335. [CrossRef]

95. Longo, L.V.G.; Breyer, C.A.; Novaes, G.M.; Gegembauer, G.; Leitão, N.P.; Octaviano, C.E.; Toyama, M.H.; de Oliveira, M.A.; Puccia, R. The human pathogen Paracoccidioides brasiliensis has a unique 1-cys peroxiredoxin that localizes both intracellularly and at the cell surface. Front. Cell Infect. Microbiol. 2020, 10. [CrossRef] [PubMed]

96. Fradin, C.; De Groot, P.; MacCallum, D.; Schaller, M.; Klis, F.; Odds, F.C.; Hube, B. Granulocytes govern the transcriptional response, morphology and proliferation of Candida albicans in human blood. Mol. Microbiol. 2005, 56, 397-415. [CrossRef] [PubMed]

97. Lorenz, M.C.; Bender, J.A.; Fink, G.R. Transcriptional response of Candida albicans upon internalization by macrophages. Eukaryot. Cell 2004, 3, 1076-1087. [CrossRef] [PubMed]

98. Barelle, C.J.; Priest, C.L.; Maccallum, D.M.; Gow, N.A.; Odds, F.C.; Brown, A.J. Niche-specific regulation of central metabolic pathways in a fungal pathogen. Cell Microbiol. 2006, 8, 961-971. [CrossRef] 
99. Chen, Y.; Toffaletti, D.L.; Tenor, J.L.; Litvintseva, A.P.; Fang, C.; Mitchell, T.G.; McDonald, T.R.; Nielsen, K.; Boulware, D.R.; Bicanic, T.; et al. The Cryptococcus neoformans transcriptome at the site of human meningitis. mBio 2014, 5, e01087-13. [CrossRef]

100. Ries, L.N.A.; Beattie, S.; Cramer, R.A.; Goldman, G.H. Overview of carbon and nitrogen catabolite metabolism in the virulence of human pathogenic fungi. Mol. Microbiol. 2018, 107, 277-297. [CrossRef]

101. Hibbett, D.S.; Binder, M.; Bischoff, J.F.; Blackwell, M.; Cannon, P.F.; Eriksson, O.E.; Huhndorf, S.; James, T.; Kirk, P.M.; Lücking, R.; et al. A higher-level phylogenetic classification of the Fungi. Mycol. Res. 2007, 111, 509-547. [CrossRef]

102. Wisecaver, J.H.; Slot, J.C.; Rokas, A. The evolution of fungal metabolic pathways. PLoS Genet. 2014, 10, e1004816. [CrossRef]

103. Shen, Q.; Rappleye, C.A. Living within the macrophage: Dimorphic fungal pathogen intracellular metabolism. Front. Cell Infect. Microbiol. 2020, 10, 592259. [CrossRef]

104. Milhomem Cruz-Leite, V.R.; Salem-Izacc, S.M.; Novaes, E.; Neves, B.J.; de Almeida Brito, W.; O'Hara Souza Silva, L.; Paccez, J.D.; Parente-Rocha, J.A.; Pereira, M.; Maria de Almeida Soares, C.; et al. Nitrogen catabolite repression in members of Paracoccidioides complex. Microb. Pathog. 2020, 149, 104281. [CrossRef]

105. De Sousa Lima, P.; Casaletti, L.; Bailão, A.M.; de Vasconcelos, A.T.R.; da Rocha Fernandes, G.; de Almeida Soares, C.M. Transcriptional and proteomic responses to carbon starvation in Paracoccidioides. PLoS Negl. Trop. Dis. 2014, 8, e2855. [CrossRef]

106. Lacerda Pigosso, L.; Baeza, L.C.; Vieira Tomazett, M.; Batista Rodrigues Faleiro, M.; Brianezi Dignani de Moura, V.M.; Melo Bailao, A.; Borges, C.L.; Alves Parente Rocha, J.; Rocha Fernandes, G.; Gauthier, G.M.; et al. Paracoccidioides brasiliensis presents metabolic reprogramming and secretes a serine proteinase during murine infection. Virulence 2017, 8, 1417-1434. [CrossRef] [PubMed]

107. Brock, M. Fungal metabolism in host niches. Curr. Opin. Microbiol. 2009, 12, 371-376. [CrossRef] [PubMed]

108. Da Silva, T.A.; Roque-Barreira, M.C.; Casadevall, A.; Almeida, F. Extracellular vesicles from Paracoccidioides brasiliensis induced M1 polarization in vitro. Sci. Rep. 2016, 6, 35867. [CrossRef] [PubMed]

109. Barbosa, M.S.; Báo, S.N.; Andreotti, P.F.; de Faria, F.P.; Felipe, M.S.; dos Santos Feitosa, L.; Mendes-Giannini, M.J.; Soares, C.M. Glyceraldehyde-3-phosphate dehydrogenase of Paracoccidioides brasiliensis is a cell surface protein involved in fungal adhesion to extracellular matrix proteins and interaction with cells. Infect. Immun. 2006, 74, 382-389. [CrossRef] [PubMed]

110. Pereira, L.A.; Báo, S.N.; Barbosa, M.S.; da Silva, J.L.; Felipe, M.S.; de Santana, J.M.; Mendes-Giannini, M.J.; de Almeida Soares, C.M. Analysis of the Paracoccidioides brasiliensis triosephosphate isomerase suggests the potential for adhesin function. FEMS Yeast Res. 2007, 7, 1381-1388. [CrossRef] [PubMed]

111. Donofrio, F.C.; Calil, A.C.A.; Miranda, E.T.; Almeida, A.M.F.; Benard, G.; Soares, C.P.; Veloso, S.N.; Soares, C.M.d.A.; Mendes Giannini, M.J.S. Enolase from Paracoccidioides brasiliensis: Isolation and identification as a fibronectin-binding protein. J. Med. Microbiol. 2009, 58, 706-713. [CrossRef]

112. Nogueira, S.V.; Fonseca, F.L.; Rodrigues, M.L.; Mundodi, V.; Abi-Chacra, E.A.; Winters, M.S.; Alderete, J.F.; de Almeida Soares, C.M. Paracoccidioides brasiliensis enolase is a surface protein that binds plasminogen and mediates interaction of yeast forms with host cells. Infect. Immun. 2010, 78, 4040-4050. [CrossRef]

113. De Oliveira, H.C.; da Silva, J.d.F.; Scorzoni, L.; Marcos, C.M.; Rossi, S.A.; de Paula e Silva, A.C.A.; Assato, P.A.; da Silva, R.A.M.; Fusco-Almeida, A.M.; Mendes-Giannini, M.J.S. Importance of adhesins in virulence of Paracoccidioides spp. Front. Microbiol. 2015, 6, 303. [CrossRef]

114. Chaves, E.G.; Weber, S.S.; Bao, S.N.; Pereira, L.A.; Bailao, A.M.; Borges, C.L.; Soares, C.M. Analysis of Paracoccidioides secreted proteins reveals fructose 1,6-bisphosphate aldolase as a plasminogen-binding protein. BMC Microbiol. 2015, 15, 53. [CrossRef]

115. Andreotti, P.F.; Monteiro da Silva, J.L.; Bailão, A.M.; Soares, C.M.d.A.; Benard, G.; Soares, C.P.; Mendes-Giannini, M.J.S. Isolation and partial characterization of a $30 \mathrm{kDa}$ adhesin from Paracoccidioides brasiliensis. Microbes Infect. 2005, 7, 875-881. [CrossRef] [PubMed]

116. Longo, L.V.G.; da Cunha, J.P.C.; Sobreira, T.J.P.; Puccia, R. Proteome of cell wall-extracts from pathogenic Paracoccidioides brasiliensis: Comparison among morphological phases, isolates, and reported fungal extracellular vesicle proteins. EuPA Open Proteom. 2014, 3, 216-228. [CrossRef]

117. Jeffery, C.J. Protein moonlighting: What is it, and why is it important? Philos. Trans. R. Soc. B 2018, 373, 20160523. [CrossRef] 
118. Rodrigues, M.L.; Nakayasu, E.S.; Oliveira, D.L.; Nimrichter, L.; Nosanchuk, J.D.; Almeida, I.C.; Casadevall, A. Extracellular vesicles produced by Cryptococcus neoformans contain protein components associated with virulence. Eukaryot. Cell 2008, 7, 58-67. [CrossRef] [PubMed]

119. Albuquerque, P.C.; Nakayasu, E.S.; Rodrigues, M.L.; Frases, S.; Casadevall, A.; Zancope-Oliveira, R.M.; Almeida, I.C.; Nosanchuk, J.D. Vesicular transport in Histoplasma capsulatum: An effective mechanism for trans-cell wall transfer of proteins and lipids in ascomycetes. Cell Microbiol. 2008, 10, 1695-1710. [CrossRef] [PubMed]

120. Oliveira, D.L.; Nakayasu, E.S.; Joffe, L.S.; Guimarães, A.J.; Sobreira, T.J.P.; Nosanchuk, J.D.; Cordero, R.J.B.; Frases, S.; Casadevall, A.; Almeida, I.C.; et al. Characterization of yeast extracellular vesicles: Evidence for the participation of different pathways of cellular traffic in vesicle biogenesis. PLOS ONE 2010, 5, e11113. [CrossRef]

121. Da Silva Jde, F.; de Oliveira, H.C.; Marcos, C.M.; da Silva, R.A.; da Costa, T.A.; Calich, V.L.; Almeida, A.M.; Mendes-Giannini, M.J. Paracoccidoides brasiliensis $30 \mathrm{kDa}$ adhesin: Identification as a 14-3-3 protein, cloning and subcellular localization in infection models. PLoS ONE 2013, 8, e62533. [CrossRef]

122. Tomazett, M.V.; Baeza, L.C.; Paccez, J.D.; Parente-Rocha, J.A.; Ribeiro-Dias, F.; de Almeida Soares, C.M. Identification and characterization of Paracoccidioides lutzii proteins interacting with macrophages. Microbes Infect. 2019, 21, 401-411. [CrossRef]

123. De Oliveira, H.C.; Castelli, R.F.; Reis, F.C.G.; Rizzo, J.; Rodrigues, M.L. Pathogenic delivery: The biological roles of Cryptococcal extracellular vesicles. Pathogens 2020, 9, 754. [CrossRef]

124. Champer, J.; Ito, J.I.; Clemons, K.V.; Stevens, D.A.; Kalkum, M. Proteomic analysis of pathogenic fungi reveals highly expressed conserved cell wall proteins. J. Fungi 2016, 2, 6. [CrossRef]

125. Lee, P.Y.; Gam, L.H.; Yong, V.C.; Rosli, R.; Ng, K.P.; Chong, P.P. Identification of immunogenic proteins of Candida parapsilosis by serological proteome analysis. J. Appl. Microbiol. 2014, 116, 999-1009. [CrossRef] [PubMed]

126. Puccia, R.; Vallejo, M.; Matsuo, A.; Longo, L. The Paracoccidioides cell wall: Past and present layers toward understanding interaction with the host. Front. Microbiol. 2011, 2, 257. [CrossRef] [PubMed]

127. Cisalpino, P.S.; Puccia, R.; Yamauchi, L.M.; Cano, M.I.N.; da Silveira, J.F.; Travassos, L.R. Cloning, characterization, and epitope expression of the major diagnostic antigen of Paracoccidioides brasiliensis. J. Biol. Chem. 1996, 271, 4553-4560. [CrossRef] [PubMed]

128. Mendes-Giannini, M.J.; Andreotti, P.F.; Vincenzi, L.R.; da Silva, J.L.; Lenzi, H.L.; Benard, G.; Zancope-Oliveira, R.; de Matos Guedes, H.L.; Soares, C.P. Binding of extracellular matrix proteins to Paracoccidioides brasiliensis. Microbes Infect. 2006, 8, 1550-1559. [CrossRef]

129. Puccia, R.; Travassos, L.R.; Rodrigues, E.G.; Camona, A.K.; Oliveira, M.C.; Juliano, L. Purification of the specific exocellular antigen gp43 from Paracoccidioides brasiliensis: Immunological and proteolytic activities. In Molecular Biology of Pathogenic Fungi: A Laboratory Manual; Maresca, B., Kobayashi, G.S., Eds.; Telos Press: New York, NY, USA, 1994; pp. 507-515.

130. De Camargo, Z.P.; Berzaghi, R.; Amaral, C.C.; Silva, S.H.M. Simplified method for producing Paracoccidioides brasiliensis exoantigens for use in immunodiffusion tests. Med. Mycol. 2003, 41, 539-542. [CrossRef]

131. Berzaghi, R.; da Silva, S.H.; de Camargo, Z.P. Variable gp43 secretion by Paracoccidioides brasiliensis clones obtained by two different culture methods. J. Clin. Microbiol. 2005, 43, 491-493. [CrossRef]

132. Magdeldin, S.; Enany, S.; Yoshida, Y.; Xu, B.; Zhang, Y.; Zureena, Z.; Lokamani, I.; Yaoita, E.; Yamamoto, T. Basics and recent advances of two dimensional- polyacrylamide gel elecTrop.horesis. Clin. Proteom. 2014, 11, 16. [CrossRef]

133. Leitão, N.P., Jr.; Vallejo, M.C.; Conceição, P.M.; Camargo, Z.P.; Hahn, R.; Puccia, R. Paracoccidioides lutzii Plp43 is an active glucanase with partial antigenic identity with P. brasiliensis gp43. PLoS Negl. Trop. Dis. 2014, 8, e3111. [CrossRef]

134. Marcos, C.M.; de Fátima da Silva, J.; de Oliveira, H.C.; Moraes da Silva, R.A.; Mendes-Giannini, M.J.S.; Fusco-Almeida, A.M. Surface-expressed enolase contributes to the adhesion of Paracoccidioides brasiliensis to host cells. FEMS Yeast Res. 2012, 12, 557-570. [CrossRef]

135. Areitio, M.; Martin-Vicente, A.; Arbizu, A.; Antoran, A.; Aparicio-Fernandez, L.; Buldain, I.; Martin-Souto, L.; Rementeria, A.; Capilla, J.; Hernando, F.L.; et al. Identification of Mucor circinelloides antigens recognized by sera from immunocompromised infected mice. Rev. Iberoam. Micol. 2020. [CrossRef] 
136. Yadav, R.K.; Shukla, P.K. A novel monoclonal antibody against enolase antigen of Aspergillus fumigatus protects experimental aspergillosis in mice. FEMS Microbiol. Lett. 2019, 366, fnz015. [CrossRef] [PubMed]

137. Santos, L.P.A.; Assunção, L.d.P.; Lima, P.d.S.; Tristão, G.B.; Brock, M.; Borges, C.L.; Silva-Bailão, M.G.; Soares, C.M.d.A.; Bailão, A.M. Propionate metabolism in a human pathogenic fungus: Proteomic and biochemical analyses. IMA Fungus 2020, 11, 9. [CrossRef] [PubMed]

138. Lapaille, M.; Thiry, M.; Perez, E.; González-Halphen, D.; Remacle, C.; Cardol, P. Loss of mitochondrial ATP synthase subunit beta (Atp2) alters mitochondrial and chloroplastic function and morphology in Chlamydomonas. Biochim. Biophys. Acta Biomembr. 2010, 1797, 1533-1539. [CrossRef] [PubMed]

139. Warner, H.R.; Duncan, B.K.; Garrett, C.; Neuhard, J. Synthesis and metabolism of uracil-containing deoxyribonucleic acid in Escherichia coli. J. Bacteriol. 1981, 145, 687-695. [CrossRef] [PubMed]

140. Vértessy, B.G.; Tóth, J. Keeping uracil out of DNA: Physiological role, structure and catalytic mechanism of dUTPases. Acc. Chem. Res. 2009, 42, 97-106. [CrossRef] [PubMed]

141. Strzalka, W.; Ziemienowicz, A. Proliferating cell nuclear antigen (PCNA): A key factor in DNA replication and cell cycle regulation. Ann. Bot. 2011, 107, 1127-1140. [CrossRef] [PubMed]

142. Bravo, R.; Frank, R.; Blundell, P.A.; Macdonald-Bravo, H. Cyclin/PCNA is the auxiliary protein of DNA polymerase-delta. Nature 1987, 326, 515-517. [CrossRef]

143. Desjardins, C.A.; Champion, M.D.; Holder, J.W.; Muszewska, A.; Goldberg, J.; Bailao, A.M.; Brigido, M.M.; Ferreira, M.E.; Garcia, A.M.; Grynberg, M.; et al. Comparative genomic analysis of human fungal pathogens causing paracoccidioidomycosis. PLoS Genet. 2011, 7, e1002345. [CrossRef]

144. Silva, P.F.; Novaes, E.; Pereira, M.; Soares, C.M.; Borges, C.L.; Salem-Izacc, S.M. In silico characterization of hypothetical proteins from Paracoccidioides lutzii. Genet. Mol. Res. 2015, 14, 17416-17425. [CrossRef]

145. Keller, N.P. Fungal secondary metabolism: Regulation, function and drug discovery. Nat. Rev. Microbiol. 2019, 17, 167-180. [CrossRef]

146. de Oliveira, H.C.; da Silva, J.d.F.; Matsumoto, M.T.; Marcos, C.M.; Peres da Silva, R.; Moraes da Silva, R.A.; Labate, M.T.V.; Labate, C.A.; Fusco Almeida, A.M.; Mendes Giannini, M.J.S. Alterations of protein expression in conditions of copper-deprivation for Paracoccidioides lutzii in the presence of extracellular matrix components. BMC Microbiol. 2014, 14, 302. [CrossRef] [PubMed]

147. Mayer, M.P.; Bukau, B. Hsp70 chaperones: Cellular functions and molecular mechanism. Cell Mol. Life Sci. 2005, 62, 670-684. [CrossRef] [PubMed]

148. Hartl, F.U.; Bracher, A.; Hayer-Hartl, M. Molecular chaperones in protein folding and proteostasis. Nature 2011, 475, 324-332. [CrossRef] [PubMed]

149. Navarro, M.V.; Chaves, A.F.A.; Castilho, D.G.; Casula, I.; Calado, J.C.P.; Conceição, P.M.; Iwai, L.K.; de Castro, B.F.; Batista, W.L. Effect of nitrosative stress on the S-nitroso-proteome of Paracoccidioides brasiliensis. Front. Microbiol. 2020, 11, 1184. [CrossRef] [PubMed]

150. Burnie, J.P.; Carter, T.L.; Hodgetts, S.J.; Matthews, R.C. Fungal heat-shock proteins in human disease. FEMS Microbiol. Rev. 2006, 30, 53-88. [CrossRef]

151. Izacc, S.M.; Gomez, F.J.; Jesuino, R.S.; Fonseca, C.A.; Felipe, M.S.; Deepe, G.S.; Soares, C.M. Molecular cloning, characterization and expression of the heat shock protein 60 gene from the human pathogenic fungus Paracoccidioides brasiliensis. Med. Mycol. 2001, 39, 445-455. [CrossRef]

152. Thomaz, L.; Nosanchuk, J.D.; Rossi, D.C.; Travassos, L.R.; Taborda, C.P. Monoclonal antibodies to heat shock protein 60 induce a protective immune response against experimental Paracoccidioides lutzii. Microbes Infect. 2014, 16, 788-795. [CrossRef]

153. Tiwari, S.; Thakur, R.; Shankar, J. Role of heat-shock proteins in cellular function and in the biology of fungi. Biotechnol. Res. Int. 2015, 2015, 132635. [CrossRef]

154. Léveillard, T.; Aït-Ali, N. Cell signaling with extracellular thioredoxin and thioredoxin-like proteins: Insight into their mechanisms of action. Oxidative Med. Cell Longev. 2017, 2017, 8475125. [CrossRef]

155. De Oliveira, A.R.; Oliveira, L.N.; Chaves, E.G.A.; Weber, S.S.; Bailão, A.M.; Parente-Rocha, J.A.; Baeza, L.C.; de Almeida Soares, C.M.; Borges, C.L. Characterization of extracellular proteins in members of the Paracoccidioides complex. Fungal Biol. 2018, 122, 738-751. [CrossRef]

156. Krahulec, S.; Armao, G.C.; Klimacek, M.; Nidetzky, B. Enzymes of mannitol metabolism in the human pathogenic fungus Aspergillus fumigatus-kinetic properties of mannitol-1-phosphate 5-dehydrogenase and mannitol 2-dehydrogenase, and their physiological implications. FEBS J. 2011, 278, 1264-1276. [CrossRef] [PubMed] 
157. Jennings, D.B.; Ehrenshaft, M.; Pharr, D.M.; Williamson, J.D. Roles for mannitol and mannitol dehydrogenase in active oxygen-mediated plant defense. Proc. Natl. Acad. Sci. USA 1998, 95, 15129-15133. [CrossRef] [PubMed]

158. Upadhyay, R.; Meena, M.; Prasad, V.; Zehra, A.; Gupta, V. Mannitol metabolism during pathogenic fungal-host interactions under stressed conditions. Front. Microbiol. 2015, 6, 1019. [CrossRef]

159. Malito, E.; Alfieri, A.; Fraaije, M.W.; Mattevi, A. Crystal structure of a Baeyer-Villiger monooxygenase. Proc. Natl. Acad. Sci. USA 2004, 101, 13157. [CrossRef] [PubMed]

160. Vasiliou, V.; Ross, D.; Nebert, D.W. Update of the NAD(P)H:quinone oxidoreductase (NQO) gene family. Hum. Genom. 2006, 2, 329. [CrossRef] [PubMed]

161. Minerdi, D.; Zgrablic, I.; Sadeghi, S.J.; Gilardi, G. Identification of a novel Baeyer-Villiger monooxygenase from Acinetobacter radioresistens: Close relationship to the Mycobacterium tuberculosis prodrug activator EtaA. Microb. Biotechnol. 2012, 5, 700-716. [CrossRef]

162. Alkan, N.; Fluhr, R.; Sherman, A.; Prusky, D. Role of ammonia secretion and ph modulation on pathogenicity of Colletotrichum coccodes on tomato fruit. Mol. Plant Microbe Interact. 2008, 21, 1058-1066. [CrossRef]

163. Alkan, N.; Davydov, O.; Sagi, M.; Fluhr, R.; Prusky, D. Ammonium secretion by Colletotrichum coccodes activates host NADPH oxidase activity enhancing host cell death and fungal virulence in tomato fruits. Mol. Plant Microbe Interact. 2009, 22, 1484-1491. [CrossRef]

164. Kim, S.Y.; Paeng, S.K.; Nawkar, G.M.; Maibam, P.; Lee, E.S.; Kim, K.S.; Lee, D.H.; Park, D.J.; Kang, S.B.; Kim, M.R.; et al. The 1-Cys peroxiredoxin, a regulator of seed dormancy, functions as a molecular chaperone under oxidative stress conditions. Plant Sci. 2011, 181, 119-124. [CrossRef]

165. Rocha, M.C.; de Godoy, K.F.; Bannitz-Fernandes, R.; Fabri, J.H.T.M.; Barbosa, M.M.F.; de Castro, P.A.; Almeida, F.; Goldman, G.H.; da Cunha, A.F.; Netto, L.E.S.; et al. Analyses of the three 1-Cys peroxiredoxins from Aspergillus fumigatus reveal that cytosolic Prx1 is central to $\mathrm{H}_{2} \mathrm{O}_{2}$ metabolism and virulence. Sci. Rep . 2018, 8, 12314. [CrossRef]

166. Tanaka, K. The proteasome: Overview of structure and functions. Proc. Jpn. Acad. Ser. B Phys. Biol. Sci. 2009, 85, 12-36. [CrossRef]

167. Potocnakova, L.; Bhide, M.; Pulzova, L.B. An introduction to B-cell epitope mapping and in silico epitope prediction. J. Immunol. Res. 2016, 2016, 6760830. [CrossRef]

168. Tomar, N.; De, R.K. Immunoinformatics: An integrated scenario. Immunology 2010, 131, 153-168. [CrossRef]

169. Larsen, J.E.; Lund, O.; Nielsen, M. Improved method for predicting linear B-cell epitopes. Immunome Res. 2006, 2, 2. [CrossRef]

170. El-Manzalawy, Y.; Dobbs, D.; Honavar, V. Predicting linear B-cell epitopes using string kernels. J. Mol. Recognit. 2008, 21, 243-255. [CrossRef]

171. Yao, B.; Zhang, L.; Liang, S.; Zhang, C. SVMTriP: A method to predict antigenic epitopes using support vector machine to integrate tri-peptide similarity and propensity. PLoS ONE 2012, 7, e45152. [CrossRef]

172. Portes, L.D.S.; Kioshima, E.S.; de Camargo, Z.P.; Batista, W.L.; Xander, P. Subtractive phage display selection for screening and identification of peptide sequences with potential use in serodiagnosis of paracoccidioidomycosis caused by Paracoccidioides brasiliensis. Lett. Appl. Microbiol. 2017, 65, 346-353. [CrossRef]

173. Caldini, C.P.; Xander, P.; Kioshima, É.S.; Bachi, A.L.; de Camargo, Z.P.; Mariano, M.; Lopes, J.D. Synthetic peptides mimic gp75 from Paracoccidioides brasiliensis in the diagnosis of paracoccidioidomycosis. Mycopathologia 2012, 174, 1-10. [CrossRef]

174. Mendes-Giannini, M.J.; Camargo, M.E.; Lacaz, C.S.; Ferreira, A.W. Immunoenzymatic absorption test for serodiagnosis of paracoccidioidomycosis. J. Clin. Microbiol. 1984, 20, 103-108. [CrossRef]

175. Ferreira-da-Cruz, M.F.; Francesconi-do-Vale, A.C.; Espinera, M.C.; Wanke, B.; Galvao-Castro, B. Study of antibodies in paracoccidioidomycosis: Follow-up of patients during and after treatment. Med. Mycol. 1990, 28, 151-157. [CrossRef]

176. Camargo, Z.P.; Taborda, C.P.; Rodrigues, E.G.; Travassos, L.R. The use of cell-free antigens of Paracoccidioides brasiliensis in serological tests. Med. Mycol. 1991, 29, 31-38. [CrossRef]

177. Fernandes, G.F.; Deps, P.; Tomimori-Yamashita, J.; Camargo, Z.P. IgM and IgG antibody response to Paracoccidioides brasiliensis in naturally infected wild armadillos (Dasypus novemcinctus). Med. Mycol. 2004, 42, 363-368. [CrossRef] 
178. Marques-da-Silva, S.H.; Colombo, A.L.; Blotta, M.H.S.L.; Queiroz-Telles, F.; Balthazar, A.B.; Lopes, J.D.; de Camargo, Z.P. Diagnosis of paracoccidioidomycosis by detection of antigen and antibody in bronchoalveolar lavage fluids. Clin. Vaccine Immunol. 2006, 13, 1363-1366. [CrossRef]

179. Carvalho, K.C.; Vallejo, M.C.; Camargo, Z.P.; Puccia, R. Use of recombinant gp43 isoforms expressed in Pichia pastoris for diagnosis of paracoccidioidomycosis. Clin. Vaccine Immunol. 2008, 15, 622-629. [CrossRef]

180. De Macedo, P.M.; Teixeira, M.d.M.; Barker, B.M.; Zancopé-Oliveira, R.M.; Almeida-Paes, R.; Francesconi do Valle, A.C. Clinical features and genetic background of the sympatric species Paracoccidioides brasiliensis and Paracoccidioides americana. PLoS Negl. Trop. Dis. 2019, 13, e0007309. [CrossRef]

Publisher's Note: MDPI stays neutral with regard to jurisdictional claims in published maps and institutional affiliations.

(C) 2020 by the authors. Licensee MDPI, Basel, Switzerland. This article is an open access article distributed under the terms and conditions of the Creative Commons Attribution (CC BY) license (http://creativecommons.org/licenses/by/4.0/). 